\title{
Psychoactive Drugs-From Chemical Structure to Oxidative Stress Related to Dopaminergic Neurotransmission. A Review
}

\author{
George Jîtcă ${ }^{1}$, Bianca E. Ősz ${ }^{1, *}$, Amelia Tero-Vescan ${ }^{2}$ and Camil E. Vari ${ }^{1}$ [D \\ 1 Department of Pharmacology and Clinical Pharmacy, Faculty of Pharmacy, George Emil Palade University of \\ Medicine, Pharmacy, Science and Technology of Târgu Mureș, 540142 Târgu Mureș, Romania; \\ george.jitca@umfst.ro (G.J.); camil.vari@umfst.ro (C.E.V.) \\ 2 Department of Biochemistry, Faculty of Pharmacy, George Emil Palade University of Medicine, Pharmacy, \\ Science and Technology of Târgu Mureș, 540142 Târgu Mureș, Romania; amelia.tero-vescan@umfst.ro \\ * Correspondence: bianca.osz@umfst.ro
}

check for updates

Citation: Jîtcă, G.; Ôsz, B.E.; Tero-Vescan, A.; Vari, C.E.

Psychoactive Drugs-From Chemical Structure to Oxidative Stress Related to Dopaminergic Neurotransmission. A Review. Antioxidants 2021, 10, 381. https://doi.org/10.3390/ antiox10030381

Academic Editor:

Ferdinando Nicoletti

Received: 22 January 2021

Accepted: 1 March 2021

Published: 4 March 2021

Publisher's Note: MDPI stays neutral with regard to jurisdictional claims in published maps and institutional affiliations.

Copyright: (c) 2021 by the authors. Licensee MDPI, Basel, Switzerland. This article is an open access article distributed under the terms and conditions of the Creative Commons Attribution (CC BY) license (https:// creativecommons.org/licenses/by/ $4.0 /)$.

\begin{abstract}
Nowadays, more and more young people want to experience illegal, psychoactive substances, without knowing the risks of exposure. Besides affecting social life, psychoactive substances also have an important effect on consumer health. We summarized and analyzed the published literature data with reference to the mechanism of free radical generation and the link between chemical structure and oxidative stress related to dopaminergic neurotransmission. This review presents data on the physicochemical properties, on the ability to cross the blood brain barrier, the chemical structure activity relationship (SAR), and possible mechanisms by which neuronal injuries occur due to oxidative stress as a result of drug abuse such as "bath salts", amphetamines, or cocaine. The mechanisms of action of ingested compounds or their metabolites involve intermediate steps in which free radicals are generated. The brain is strongly affected by the consumption of such substances, facilitating the induction of neurodegenerative diseases. It can be concluded that neurotoxicity is associated with drug abuse. Dependence and oxidative stress are linked to inhibition of neurogenesis and the onset of neuronal death. Understanding the pathological mechanisms following oxidative attack can be a starting point in the development of new therapeutic targets.
\end{abstract}

Keywords: oxidative stress; toxicity; bath salts; phenethylamine derivatives; dopamine

\section{Introduction}

Amphetamine was first synthesized in 1887 by the chemist L. Edeleanu, being the leader of a group of compounds that have structural similarities and common biological effects. Amphetamine is currently approved by the FDA for the treatment of attention deficit disorder (ADHD) and narcolepsy, and some amphetamine derivatives are licensed for both ADHD and obesity treatment [1]. These substances are closely monitored by drug agencies because of their potential for abuse. The acute effects of the use of these substances include euphoria, increased alertness and psychomotor activity, decreased appetite, and even loss of appetite and hyperthermia. Long-term abuse causes psychotic, paranoid, aggressive and, above all, neurotoxic states [2]. Amphetamine derivatives promote oxidative stress by decreasing the gene expression of the antioxidant enzymes $\mathrm{Cu}$ Zn superoxide dismutase (SOD), catalase (CAT) or glutathione peroxidase (GPx). Excessive heat production that induces hyperthermia and the pro-catabolic status facilitates the conversion of the enzyme xanthine dehydrogenase to the oxidizing form [3].

Synthetic derivatives of cathinones ( $\beta$-keto-amphetamines), also called "bath salts", are compounds with a stimulating effect. Their structure is derived from cathinone, a substance found in the khat plant, Catha edulis, a shrub cultivated in East Africa and South Arabia, consumed by local people for its mild stimulating effect [4]. Cathinones are used as cheap substitutes for other central stimulants, such as amphetamines or cocaine. Although the chemical structure of cathinones is similar to that observed in the structure 
of amphetamines, synthetic cathinones possess distinct psychopharmacological properties [5]. The structure of $\beta$-keto-amphetamine gives cathinones similar but not identical effects to amphetamine. Cathinones possess the ability to increase the concentration of catecholamines and serotonin (5-HT) by blocking specific transporters, but the psychopharmacological spectrum and illicit use differ [6]. If amphetamine is used more for its anorexigenic and stimulant properties, cathinones have evolved from "chemsex" to "slam" (by injection), due to entactogenic effects, to enhance sensory perceptions and sexual performance [6]. The mechanism of action of classical amphetamine derivatives and cathinones has been intensively studied. Currently, the proposed mechanisms for cathinones combine both cocaine-like properties (inhibition of dopamine (DA) and norepinephrine (NA) reuptake by blocking specific transporters) and amphetamine-like (interaction with the vesicular transporter of monoamines VMAT2, reversal of the reuptake direction and favoring efflux of neurotransmitters DA and/or NA).

Depending on the belongingness to one of the generation and the cellular transduction mechanism, cathinones can be grouped as follows [7-12]:

- cocaine-3,4-methylenedioxymethamphetamine (MDMA)—mixed group, non-selective monoamine reuptake inhibitors (cocaine-like), with preferential selectivity for dopamine transporter (DAT), but favoring the release of 5-HT like MDMA (e.g., mephedrone, methylone, ethylone, naphyrone);

- methamphetamine-like cathinones group, catecholamine reuptake inhibitors and DA liberators (e.g., methcathinone, flephedrone);

- pyrovalerone-derived compounds, catecholamine reuptake inhibitors, without a liberating action (e.g., 3,4-methylenedioxypyrovalerone also known as MDPV, 3,4methylenedioxy- $\alpha$-pyrrolidinobutiophene also known as MDPBP, $\alpha$-pyrrolidinovalero phenone also known as $\alpha$-PVP);

Being compounds intended for sale on the black market, "bath salts" are more often than not chemically pure compounds and do not represent a fixed combination of substances. Clinical data on the toxicity of pure cathinone consumption are rare, and case reports describe nonspecific symptoms, easily confused with other ones, and can mimic various conditions. Therefore, it is difficult to draw clear conclusions and appropriate therapeutic behavior. According to Drug of Abuse, A DEA Resource Guide, 2020 Edition [13], for drug addicts, the preferred routes of administration of "bath salts" are sniffing, but they can also be taken orally, smoked or injected. In the case of amphetamines, according to the same source, they are taken orally, injected or smoked. According to European Monitoring Centre for Drugs and Drug Addiction (EMCDDA 2020 report) [14], considering the route of administration of amphetamines, 52\% reported sniffing, 15\% reported oral consumption, $15 \%$ reported smoking, and $17 \%$ reported injection. Concerning the excitotoxicity of the two classes of substances, this is a picture made up of several successive events: massive release of glutamate (GLU), followed by the activation of specific receptors; as a result, there will be an increase in the intracellular calcium concentration. This signaling pathway will lead to activation of calcium-dependent enzymes, followed by the generation of reactive oxygen (ROS) and nitrogen species (RNS), and then to the activation of apoptotic mechanisms $[2,15]$. As a general mechanism of action, most synthetic cathinones have similarities to amphetamines-promoting DA, NA and 5-HT neuronal transmissions. Inhibition of catecholamine reuptake, similar to cocaine, is also described [16]. An attempt to establish cellular and molecular mechanisms generating ROS at the neuronal level and the involvement of amphetamines and cathinone derivatives in neurotoxicity may serve to discover therapeutic approaches to prevent the onset of negative consequences for human beings.

\section{Materials and Methods}

Data presented in this article were obtained following a literature search in four electronic databases: ScienceDirect, PubMed, PLOS, and Google Scholar. Inclusion criteria for articles were: title analysis, content of the abstract, and especially the information contained/included in the article. At the end of this review, data are presented on antioxidant 
therapy and how this therapy can have beneficial effects, reducing the toxic effects of these drugs diverted from medical use and/or trafficked illicit substances.

\section{Results}

This section presents data on chemical structure, the relationship between structure and pharmacological activity. At the same time, the influence of these psychoactive drugs on the levels of neurotransmitters is discussed, in particular DA, their mechanism of action being specified, correlated with the property of generating oxidative stress.

\subsection{Transendothelial Blood Brain Barrier and Lipophilicity}

In order to evaluate the neurotoxicity induced by cathinone and amphetamine derivatives, it is necessary to study the influences on the transporters and receptors of catecholamines; the result of the interaction is to modify the normal signaling pathways qualitatively and/or quantitatively. These biological targets are subject to cytotoxicity exerted as a result of the induction of oxidative stress. Thus, the neurotoxicity induced by these two classes of drugs is based on their ability to trigger inflammatory processes leading to irreparable degeneration (i.e., irreversible cytotoxicity). The relationship between neuronal toxicity and degeneration is closely related to the amount of drug reaching the central nervous system (CNS). The differences between the compounds (cathinone derivatives and non- $\beta$-keto-amphetamine analogues) are due to the different abilities to cross the blood-brain barrier (BBB). As the target of these drugs is the brain, the ability to reach the level of this organ depends not only on the route of administration, but also on their physicochemical properties (which determines the BBB penetration). In addition, it is possible that altered barrier function could cause the effects associated with neurotoxicity. It is known that molecules with a permeability index greater than 1 can easily cross the BBB. It is important to note that the compounds with a permeability index greater than or equal to 3 have a high permeability, and those with an index greater than 10 have a very high permeability. MDPV presents the highest degree of lipophilicity. This characteristic is due to the pyrrolidine ring and to the tertiary amino group which characterizes a compound with very low polarity and results in a high penetrating capacity of the BBB [17]. Abuse is associated with changes in the permeability of the BBB. In addition, excitotoxicity is added to this change which affects the distribution of the drug and is associated with a massive generation of ROS. This is the mechanism of induced neurotoxicity [18].

\subsection{Influence of Neurotransmitter Transporters, Vesicular Transporters, and Receptors}

Regarding the modification of the action of monoaminergic systems, this is one of the characteristics of amphetamine derivatives, and this influence will be discussed in more detail (including cathinone analogues).

Thus, the neurotoxicity exerted by amphetamine is due to the depletion of DA and 5-HT, inhibition of enzymes involved in the biosynthesis of neurotransmitters, tyrosine hydroxylase (TH) and tryptophan hydroxylase 2 (TPH-2), inactivation of DAT and serotonin transporter (SERT), and reduction of VMAT2 function [19], promoting apoptosis and neuronal degeneration.

Methamphetamine is known to have negative effects on the striatum (neurotoxicity due to dysregulation of mitochondrial function, neuronal energetic imbalance, overproduction of ROS, degeneration of axon terminals) especially on DA nerve endings. These effects could be a consequence of long term DA depletion and decreased DA synthesis due to reduced TH activity $[2,17,20-22]$.

Although the number of studies is limited, the effects of $\beta$-keto-amphetamine compounds appear to be more complex, influencing more neurotransmissions; methcathinone is known to be selective in the release of mediators (it has the ability to release DA predominantly, but the serotonergic mechanism cannot be ruled out either) $[9,17,23,24]$. At repeated doses, the activity of DAT, SERT, enzymes involved in the biosynthesis of catecholamines, $\mathrm{TH}$, and TPH-2 decreases. Regarding mephedrone, it has the property of releasing DA 
(similar to methamphetamine, but much weaker), but the influence on DA neurons is greater than that exerted by MDMA. Microdialysis studies performed on rat brains showed that methamphetamine and mephedrone increase the extracellular level of 5-HT (as opposed to amphetamine), which can be considered a qualitatively different pharmacological effect $[8,25,26]$.

Experimental data conducted on brain synaptosomes of rats demonstrate that mephedrone and methylone are non-selective inhibitors of the DAT, norepinephrine transporter (NET) and SERT, causing an increase in the extracellular level of DA and 5HT [7,8,11,25,27-29]. Microdialysis experiments show that pyrovalerone and MDPV derivatives increase the extracellular concentration of DA in the nucleus accumbens, (NAc) [25], these derivatives having a higher inhibitory capacity against DAT, being among the most important inhibitors $[9,25,29]$. On the other hand, these compounds do not have the property of stimulating the release of DA $[7,17,30]$.

To sum up, DA is the main factor generating negative effects, having a stronger influence compared with 5-HT. This is due to the increased susceptibility of DA neurons to enzymatic and non-enzymatic oxidative processes [31-34].

\subsection{Mechanisms of Action}

Both groups of psychotropic drugs discussed, due to their psychostimulant effects, are classified as responsible for misuse and abuse. These effects can occur through two distinct mechanisms:

- cocaine-like mechanism (inhibition of DA and NA reuptake following DAT and NET blockade) $[35,36]$;

- amphetamine-like mechanism (favoring the outflow of DA and/or NA neurotransmitters) $[37,38]$;

In the case of amphetamine compounds, two other accessory mechanisms that contribute to the occurrence of neurotoxicity have been discovered:

- VMAT interaction (modifying the $\mathrm{pH}$ by decreasing the proton gradient along the membrane, inducing the release of monoamines from the vesicles to the cytosol) [39-42];

- $\quad$ inhibition of monoamine oxidase (MAO) and/or catechol-ortho-methyltransferase (COMT) [43-46];

Unlike amphetamine derivatives, mephedrone and methylone lack affinity for the VMAT transporter. This difference is reflected in a lower degree of neurotoxicity. Concomitant use of methamphetamine and mephedrone or methylone worsens the toxic effects (addition of side effects); nevertheless, the use of methamphetamine with MDPV has been shown to have protective effects, because, MDPV, by blocking DAT mediated transport (inward or outward), blocks methamphetamine-induced dopamine release [17,47].

Pyrovalerone derivatives such as MDPV (a potent DAT inhibitor), show their psychotic effects at lower doses. Also, they have a high degree of lipophilicity, crossing the BBB more easily. The increased potency of inhibiting DAT and SERT is related to the addictive potential, whereas lipophilia is linked to the ability to cross the BBB, which may be correlated with the latency of psychoactive effects. Also, the promotion of DA neurotransmission by the psychoactive drugs (e.g., MDPV, $\alpha-P V P, \alpha-P P P)$ is due to inhibition of DAT and accumulation of DA in the synaptic cleft. Moreover, 5-HT accumulated in the synaptic cleft as a result of the interaction with SERT (e.g., mephedrone, naphyrone, MDMA) enhances DA activity through post synaptic 5-HT2A receptors, which favors the release of DA [7-9,11,48]. The 5-HT and DA interaction in NAc is complex, the addictive properties can be mediated by the increase of the DA level in the ventral striatum (the increase in DA release is directly responsible for activating the reward system) $[49,50]$. The vasoconstriction and hyperthermia induced by compounds such as amphetamine, methamphetamine, methcathinone, mephedrone or flephedrone is the consequence of the stimulation of peripheral $\alpha 1 \mathrm{~A}$ and $\alpha 2 \mathrm{~A}$ adrenergic receptors. Thus, we can explain the toxic sympathomimetic effects observed regularly after intoxication [9]. 


\subsection{Structure Activity Relationship}

\subsubsection{Cathinone Derivatives}

The study of the relationship between structure and activity aims to establish the influence of chemical structure on biological action (see Figure 1 for chemical structures). The purpose is to identify the substituents which modify the activity (in particular the type of action, the potency, the affinity). For the compounds examined, the actions of a number of agents may be related to their ability to activate a specific receptor in the brain. The reason why it is important to know the structure-activity relationship (SAR) is that the number of new synthetic compounds derived from cathinone is constantly increasing. Thus, the report of EMCDDA 2020, identifies approximately 100 new derivatives of synthetic cathinones in 2018 , compared with approximately 10 structures in 2008. In Europe, approximately $36 \%$ of the amount of confiscated new psychoactive drugs is dominated by syntethic cathinones (quantitatively, synthetic cathinones and cannabinoids accounting for more than three quarters of the total). Undoubtedly, new compounds will continue to appear due to the knowledge regarding the chemical structure pharmacological effect relationships [24].

In the case of substituted 4-MCAT derivatives (e.g., mephedrone, flephedrone), the selectivity for DAT vs SERT may explain the addictive behavior (dopamine-related reward system), relative to the hallucinogenic potential, which is not necessarily related to dependence.

Butylone, the compound with the ethyl group in the $\alpha$ position of the 2-methylamino1-(3,4-methylenedioxyphenyl) propan-1-one (MDMC) side chain (instead of the methyl group) acts as an inhibitor of DA, NA, and 5-HT reuptake by blocking the three specific transporters DAT, NET, and SERT. The presence of the $\alpha$-ethyl group (specific to MBDB and butylone structures) decreases the ability to induce euphoria and thus the risk of abuse due to a reduced ability to interact with the NET carrier. Thus, the $\alpha$-methyl group (from the structure of MDMA or methylone) is responsible for the preferential inhibition of NET and the high potential for abuse [9].

In addition, the increase in chain length (change of methylenedioxy from MDMC to ethylendioxy, specific for EDMC) decreases the ability of substances to cause the release of the three mediators [51].

Naphyrone is obtained if the methylenedioxy ring of MDPV is replaced by an aromatic (phenyl) ring. This compound behaves as a blocker of the three carriers (DAT, NET, SERT); however, the blocking action occurs preferentially on SERT and to a lesser extent on NET and DAT (the main difference between naphyrone and MDPV) [9]. A pyrrolidine ring and a flexible alkyl chain in the $\alpha$ position (e.g., MDPV) can be added to block the DAT transporter. The introduction of the 3,4-methylenedioxy group does not have major consequences, as demonstrated by Marusich et al. [52]. As a result, the removal of the 3,4-methylenedioxy group from MDPV to form $\alpha$-PVP has negligible effects on the ability to block DAT or NET in rat brain synaptosomes. Furthermore, the introduction of a pyrrolidine ring to any cathinonic analogue (e.g., MDPV, MDPBP, 3,4-methylenedioxy$\alpha$-pyrrolidinopropiophenone also known as MDPPP) can be used to confer the specific blocking properties of both catecholamine transporters (DAT, NET) [10,53-56].

Conclusions resulting from the study of SAR are difficult to draw, most of the studies having focused on the determination of the pharmacokinetic (administration route)/pharmacodynamic (pharmacological effects) properties of the synthesized compounds, without making a real initial selection based on potential properties through in silico modeling. While there are many studies on in silico modeling of SAR in the case of cathinones, they remain in the field of academic research. On the black market, the selection of new compounds is based on the already discovered old structures, the goal not necessarily being to change the properties (lipophilicity, selectivity for DAT, SERT, etc.), but above all to avoid the introduction of compounds on the prohibited list. As a result, most of the new compounds, later classified into generations, were designer molecules of the old compounds, the list having to be constantly updated by the legislator [57-63]. The DAT vs SERT ratios of synthetic cathinones are presented in Table 1. 


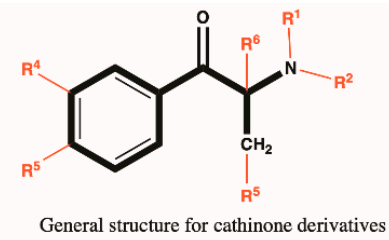<smiles>CC(N)C(=O)c1ccccc1</smiles><smiles>CCN(CC)C(C)C(=O)c1ccccc1</smiles><smiles>CNC(C)C(=O)c1ccccc1</smiles><smiles>CCCC(C(=O)c1ccccc1)N1CCCC1</smiles><smiles>CCCC(C(=O)c1cccs1)N1CCCC1</smiles><smiles>CNC(C)C(=O)c1ccc2c(c1)OCO2</smiles><smiles>CCCC(NC)C(=O)c1ccc2c(c1)OCO2</smiles><smiles>CC(C(=O)c1ccc2c(c1)OCO2)N1CCCC1</smiles><smiles>CNC(C)C(=O)c1ccccc1</smiles><smiles>CCC(NC)C(=O)c1ccccc1</smiles><smiles>CNC(C)C(=O)c1ccc(C)cc1</smiles><smiles>CCCC(C(=O)c1ccc(C)cc1)N1CCCC1</smiles><smiles>CCCCC(C(=O)c1ccc(C)cc1)N1CCCC1</smiles><smiles>CC(N)C(=O)c1ccc2c(c1)OCO2</smiles><smiles>CCCC(NC)C(=O)c1ccc2c(c1)OCO2</smiles><smiles>CCCC(C(=O)c1ccc2c(c1)OCO2)N1CCCC1</smiles><smiles>CNC(C)C(=O)c1ccc(C)cc1</smiles><smiles>CCCC(NC)C(=O)c1ccccc1</smiles><smiles>CNC(C)C(=O)c1cccc(F)c1</smiles><smiles>CC(C(=O)c1ccccc1)N1CCCC1</smiles><smiles>CNC(C)C(=O)c1ccc(C)cc1</smiles><smiles>CCC(NC)C(=O)c1ccc2c(c1)OCO2</smiles><smiles>CCC(C(=O)c1ccc2c(c1)OCO2)N1CCCC1</smiles><smiles>CCCC(C(=O)c1ccc2ccccc2c1)N1CCCC1</smiles>

Figure 1. Chemical structure of cathinone derivatives. 
Table 1. In vitro dopamine and serotonin uptake transporter inhibition ( $\mathrm{IC}_{50}$ values) and release data (EC $\mathrm{E}_{50}$ values).

\begin{tabular}{|c|c|c|c|c|c|c|c|c|}
\hline \multirow[b]{2}{*}{ Compound } & \multicolumn{4}{|c|}{ Monoamine Uptake Transporter Inhibition $\left(\mathrm{IC}_{50}\right)$} & \multicolumn{4}{|c|}{ Monoamine Release $\left(\mathrm{EC}_{50}\right)$} \\
\hline & DAT & SERT & $\begin{array}{l}\text { DAT/SERT } \\
\text { Ratio }\end{array}$ & Ref. & DAT & SERT & $\begin{array}{l}\text { DAT/SERT } \\
\text { Ratio }\end{array}$ & Ref. \\
\hline Cathinone & $14.0(10-20) *$ & $>100 *$ & $>10 *$ & [9] & $5.64(3.0-10) *$ & $>100 *$ & na & [9] \\
\hline Methcathinone & $\begin{array}{c}1.12(0.83-1.5)^{*} \\
2.4(1.7-3.4)^{*}\end{array}$ & $\begin{array}{c}>10 * \\
46(30-71) *\end{array}$ & $\begin{array}{c}>10^{*} \\
19(8.8-42) *\end{array}$ & $\begin{array}{c}{[9]} \\
{[64]}\end{array}$ & $\begin{array}{c}2.36(1.7-3.3)^{*} \\
12.5^{* *}\end{array}$ & $\begin{array}{c}>33^{*} \\
3.860^{* *}\end{array}$ & $\begin{array}{c}\text { na } \\
309^{* *}\end{array}$ & $\begin{array}{c}{[9]} \\
{[56]}\end{array}$ \\
\hline Mephedrone & $\begin{array}{l}3.31(2.6-4.2)^{*} \\
1.4(1.2-1.4)^{*} \\
5.7(4.5-7.2)^{*} \\
970 \pm 50^{* *} \\
762 \pm 79^{* *}\end{array}$ & $\begin{array}{c}4.64(3.7-5.9)^{*} \\
83(66-104) \\
3.6(2.8-4.6)^{*} \\
310 \pm 80 * * \\
422 \pm 26^{* *}\end{array}$ & $\begin{array}{c}1.4(0.9-2.4) * \\
\text { na } \\
0.63(0.39-1.02) * \\
\text { na } \\
\text { na }\end{array}$ & $\begin{array}{c}{[9]} \\
{[65]} \\
{[66]} \\
{[7]} \\
{[10]}\end{array}$ & $\begin{array}{l}3.75(1.7-8.4)^{*} \\
49.1 \pm 8.32 * *\end{array}$ & $\begin{array}{l}5.98(3.2-11)^{*} \\
118.3 \pm 25.9 \text { ** }\end{array}$ & $\begin{array}{c}\text { na } \\
2.41^{* *}\end{array}$ & $\begin{array}{c}{[9]} \\
{[10]}\end{array}$ \\
\hline Buphedrone & $4.24(3.3-5.5) *$ & $70(2-2700) *$ & $>10 *$ & [67] & & & & \\
\hline Pentedrone & $\begin{array}{l}2.5(2.0-3.2)^{*} \\
0.4(0.3-0.4)^{*}\end{array}$ & $\begin{array}{c}135(5-3700) * \\
16(14-18)^{*}\end{array}$ & $\begin{array}{c}>10^{*} \\
\text { na }\end{array}$ & $\begin{array}{l}{[67]} \\
{[65]}\end{array}$ & $>100 *$ & $>100 *$ & na & [55] \\
\hline Methedrone & $35(15-79) *$ & $4.73(3.2-6.9) *$ & $0.14(0.04-0.46) *$ & [67] & $506^{* *}$ & $120 * *$ & $0.24 * *$ & [56] \\
\hline Flephedrone & $6.35(4.2-9.5) *$ & $>10 *$ & $5.8(0.8-41) *$ & [9] & $\begin{array}{c}12.5(5.7-28) * \\
83.4^{* *}\end{array}$ & $\begin{array}{l}>33^{*} \\
1290^{* *}\end{array}$ & $\begin{array}{c}\text { na } \\
15.4^{* *}\end{array}$ & $\begin{array}{c}{[9]} \\
{[56]}\end{array}$ \\
\hline 3-FMC & $1.7(1.0-3.0) *$ & $56(7-472) *$ & $>10 *$ & [67] & & & & \\
\hline Pyrovalone & $0.035(0.03-0.04)$ * & $13.0(10.8-15.8)$ * & $>100 *$ & [9] & & & & \\
\hline$\alpha-P V P$ & $\begin{array}{c}0.2(0.1-0.3)^{*} \\
0.04(0.01-0.1)^{*} \\
12.8^{* *}\end{array}$ & $\begin{array}{c}237(196-291)^{*} \\
>100^{*} \\
>10,000^{* *}\end{array}$ & $\begin{array}{c}\text { na } \\
>1000 * \\
>781^{* *}\end{array}$ & $\begin{array}{l}{[65]} \\
{[64]} \\
{[56]}\end{array}$ & $>100 *$ & $>100 *$ & na & [55] \\
\hline$\alpha$-PPP & $\begin{array}{c}0.540 \pm 0.076^{*} \\
196^{* *}\end{array}$ & $\begin{array}{l}188 \pm 12 * \\
>10,000^{* *}\end{array}$ & $\begin{array}{c}\text { na } \\
>51^{* *}\end{array}$ & $\begin{array}{l}{[55]} \\
{[56]}\end{array}$ & $>10$ & $>10$ & na & [55] \\
\hline$\alpha-\mathrm{PVT}$ & $0.342 \pm 0.0049 *$ & $242 \pm 41 *$ & na & [55] & & & & \\
\hline 3,4-DMMC & $9.4(7.6-11.7)^{*}$ & $1.1(0.9-1.4)$ * & $0.12(0.08-0.18)$ * & {$[66]$} & & & & \\
\hline Methylone & $\begin{array}{c}4.82(3.8-6.1) * \\
2.0(1.7-2.3) * \\
560 \pm 50 * * \\
12320 \pm 133 * *\end{array}$ & $\begin{array}{c}15.5(10-26)^{*} \\
68(58-80)^{*} \\
230 \pm 30 * * \\
1017 \pm 59 * *\end{array}$ & $\begin{array}{c}3.3(1.5-6.8)^{*} \\
\text { na } \\
\text { na } \\
\text { na }\end{array}$ & $\begin{array}{c}{[9]} \\
{[65]} \\
{[11]} \\
{[10]}\end{array}$ & $\begin{array}{c}>100 * \\
133.0 \pm 11.2 * * \\
117 \pm 12 \text { ** }\end{array}$ & $\begin{array}{c}>10^{*} \\
242.1 \pm 48.3 * * \\
234 \pm 35^{* *}\end{array}$ & $\begin{array}{c}\text { na } \\
1.82^{* *} \\
\text { na }\end{array}$ & $\begin{array}{l}9] \\
{[8]} \\
{[10]}\end{array}$ \\
\hline Ethylone & $5.68(4.9-6.5) *$ & $4.46(3.8-5.2) *$ & $0.8(0.6-1.1) *$ & [9] & $\begin{array}{l}>100 * \\
>10^{*}\end{array}$ & $\begin{array}{l}9.9(2.4-40) \text { * } \\
1.48 \pm 0.25 \text { * }\end{array}$ & $\begin{array}{l}\text { na } \\
\text { na }\end{array}$ & $\begin{array}{l}{[9]} \\
{[55]}\end{array}$ \\
\hline Butylone & $\begin{array}{c}2.9(2.5-3.4)^{*} \\
1710 \pm 320 * * \\
400 \pm 20 * *\end{array}$ & $\begin{array}{c}6.22(4.3-9.0)^{*} \\
680 \pm 130 * * \\
1430 \pm 16^{* *}\end{array}$ & $\begin{array}{c}2.1(1.3-3.6) * \\
\text { na } \\
\text { na }\end{array}$ & $\begin{array}{l}{[9]} \\
{[11]} \\
{[68]}\end{array}$ & $>100 *$ & $\begin{array}{c}5.5 \\
(1.8-17) *\end{array}$ & na & [68] \\
\hline Pentylone & $\begin{array}{c}1.34(1.0-1.7)^{*} \\
120 \pm 10^{* *}\end{array}$ & $\begin{array}{l}8.37(5.4-13) * \\
1360 \pm 100 * *\end{array}$ & $\begin{array}{c}6.2(3.2-13) * \\
\text { na }\end{array}$ & $\begin{array}{l}{[67]} \\
{[68]}\end{array}$ & $\begin{array}{l}>100 * \\
(-)^{* *}\end{array}$ & $\begin{array}{c}>100 * \\
1030 \pm 180 * *\end{array}$ & $\begin{array}{l}\text { na } \\
\text { na }\end{array}$ & $\begin{array}{l}{[55]} \\
{[68]}\end{array}$ \\
\hline MDPBP & $0.11(0.07-0.16) *$ & $15(5.4-39)^{*}$ & $132(34-557) *$ & [64] & $>10 *$ & $>10 *$ & na & [55] \\
\hline MDPP & $\begin{array}{c}1.08 \pm 0.1{ }^{*} \\
0.53(0.27-1.1)^{*}\end{array}$ & $\begin{array}{c}126 \pm 36^{*} \\
75(49-114)^{*}\end{array}$ & $\underset{141(45-422)}{\text { na }}$ & $\begin{array}{l}{[69]} \\
{[64]}\end{array}$ & $>10 *$ & $>10 *$ & na & [55] \\
\hline MDPV & $\begin{array}{c}0.031(0.03-0.04)^{*} \\
0.07(0.07-0.08)^{*} \\
0.05(0.04-0.06)^{*} \\
4.1 \pm 0.5^{* *}\end{array}$ & $\begin{array}{l}9.3(6.8-12.8)^{*} \\
4.5(4.0-5.2)^{*} \\
9.6(3.4-27) * \\
3305 \pm 305^{* *}\end{array}$ & $\begin{array}{c}>100 * \\
\text { na } \\
192(57-675) * \\
\text { na }\end{array}$ & $\begin{array}{c}{[9]} \\
{[65]} \\
{[64]} \\
{[10]}\end{array}$ & $2.3 \pm 0.8^{* *}$ & $>100 *$ & na & [9] \\
\hline
\end{tabular}

3-FMC = 3-Fluoromethcathinone; DAT $=$ dopamine transporter; SERT $=$ serotonin transporter; $(-)=$ inactive; na $=$ not reported by authors; $\mathrm{DAT} / \mathrm{SERT}$ ratio $=\left(\mathrm{DAT} \mathrm{IC}_{50}\right)^{-1} /\left(\mathrm{SERT} \mathrm{IC}_{50}\right)^{-1}, \mathrm{DAT} / \mathrm{SERT}$ ratio $=\left(\mathrm{DAT} \mathrm{EC}_{50}\right)^{-1} /\left(\mathrm{SERT} \mathrm{EC}_{50}\right)^{-1}$; values are expressed as mean or means $\pm \mathrm{SD}$, similar to original articles. The ability of tested drugs to inhibit the transport-mediated uptake is expressed as $\mathrm{IC}_{50}$. The ability of tested drugs to influence the transporter-mediated release is expressed as $\mathrm{EC}_{50}$ * * in vitro studies for neurotransmitter reuptake inhibition and release using HEK293 (Human Embryonic Kidney 293) cell line expressing DAT and SERT (IC 50 and EC 50 values are expressed in $\mu$ M). ** in vitro studies for neurotransmitter reuptake inhibition and release from rat brain synaptosomes $\left(\mathrm{IC}_{50}\right.$ and $\mathrm{EC}_{50}$ values are expressed in $\mathrm{nM})$.

\subsubsection{Amphetamine Derivatives}

For amphetamine derivatives with general structure presented in Figure 2, the introduction of the ethyl group in the $\alpha$ position (e.g., MBDB) decreases the possibility of influencing the central dopaminergic pathways. Alkylation of the amino group (e.g., methamphetamine, MDMA, MBDB, 3,4-methylenedioxy-N-ethylamphetamine also known as MDEA) alters the intracerebral distribution of the compound, but also greatly influences the pharmacokinetic parameters [48,70]. Substitutions in the aromatic nucleus change the type of effect, with a diversification of the biological response: fenfluramine behaves like a sedative and produces dysphoria, while MDMA is a central stimulant drug which produces 
marked euphoria [56,71,72]. There are also compounds with an $\alpha, \alpha^{\prime}$-dimethyl structure derived from MDMA or MBDB (such as 3,4-methylenedioxyphentermine). In addition, alkylation to the amino group (for example, the N-methyl analogue) leads to a special pharmacological profile- they do not produce the release of 5-HT from the synaptosomes of the rat brain [56]. Since the discovery of the class of amphetamine derivatives, it has been demonstrated that the substitution of the aromatic ring by a bulky group increases the selectivity for SERT to the detriment of DAT; thus, 3-norfenfluramine behaves as a preferred substrate for SERT as opposed to amphetamine, the parent compound [73,74]. The chemical structures of amphetamine derivatives are presented in Figure 2.

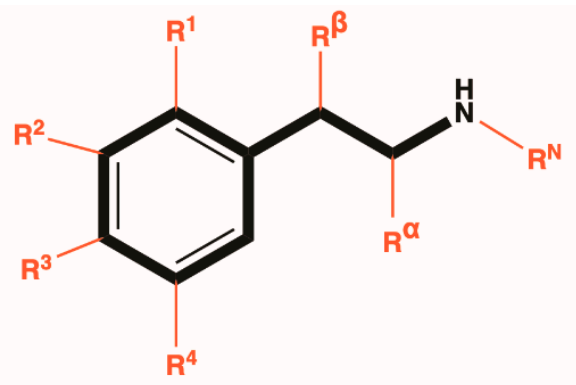

General structure of beta-phenylethylamine derivatives

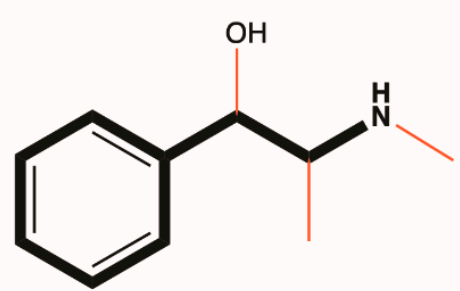

Ephedrine

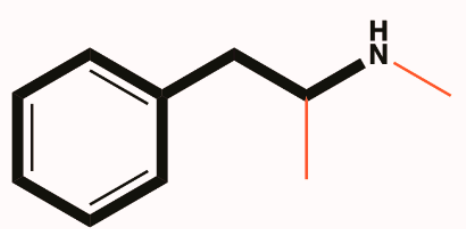

Methamphetamine

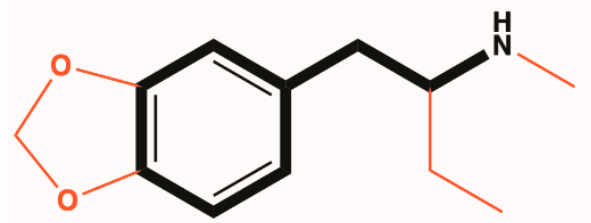

MBDB

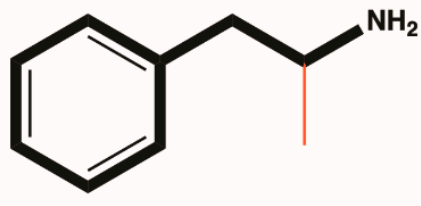

Amphetamine

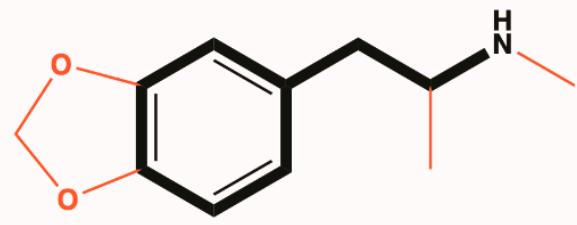

MDMA

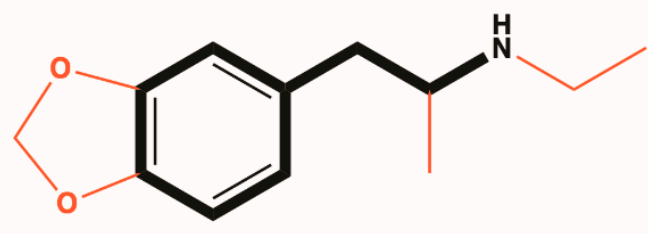

MDEA

Figure 2. Chemical structures of amphetamine derivatives.

Based on the relationship between structure and activity, amphetamine analogues and cathinone derivatives have similar pharmacological/psychopharmacological effects. The similarities consist of the main structural core ( $\beta$-phenylethylamine) which confers peripheral and central sympathomimetic action. The extension in the hydrocarbon chain increases the lipophilicity of the molecule and provides protection against enzymatic degradation (e.g., $\alpha$-PVP, Pyrovalerone, Pentylone, N-ethylpentylone, MDPV, MBDB) [70].

The therapeutic target for drugs (amphetamine and cathinone derivatives) are represented by DAT, NET, and SERT. The cause of this similarity is the presence of a common 
pharmacophore in the molecule. Alkylation of the amino group (addition of an N-methyl group to amphetamine) alters the selectivity to transporters (increases to SERT vs DAT, does not change to NET) -also, the introduction of the methylenedioxy group (in the case of MDMA) leads to an increased selectivity for SERT (which explains the differences in psychotoxicity between amphetamine and MDMA) [75].

The $\beta$-ketone analogue of methamphetamine (methcathinone) has diminished adrenergic effects, maintaining the intensity of dopaminergic ones. For substances with high affinity for SERT, the way to induce oxidative stress is different, because 5-HT is not directly involved in the generation of free radicals [76,77]. Increased 5-HT levels can lead to the onset of serotonin syndrome (manifested as tachycardia, hypertension, hyperthermia) and it can have a significant social impact due to the fact that the accumulated 5-HT has the ability to stimulate postsynaptic 5-HT2A receptors leading to increase DA release in NAc $[49,50]$. These effects can be indirectly correlated with oxidative stress. The more recurrent need for higher doses due to more frequent misuse also increases the availability of DA, as the selectivity towards SERT is only preferential, nevertheless, the release and inhibition of DA reuptake still remain relatively noticeable [70]. The DAT vs SERT ratios of amphetamine derivatives and cocaine are presented in Table 2.

Table 2. In vitro dopamine and serotonin uptake transporter inhibition ( $\mathrm{IC}_{50}$ values) and release data (EC 50 values).

\begin{tabular}{|c|c|c|c|c|c|c|c|c|}
\hline \multirow[b]{2}{*}{ Compound } & \multicolumn{4}{|c|}{ Monoamine Uptake Transporter Inhibition $\left(\mathrm{IC}_{50}\right)$} & \multicolumn{4}{|c|}{ Monoamine Release $\left(\mathrm{EC}_{50}\right)$} \\
\hline & DAT & SERT & $\begin{array}{c}\text { DAT/SERT } \\
\text { Ratio }\end{array}$ & Ref. & DAT & SERT & $\begin{array}{c}\text { DAT/SERT } \\
\text { Ratio }\end{array}$ & Ref. \\
\hline \multirow{3}{*}{ Amphetamine } & $1.3(0.83-2.0) *$ & $>10^{*}$ & $>10 *$ & [9] & $2.36(1.7-3.3) *$ & $>33 *$ & na & [9] \\
\hline & $1.3(0.8-2.0)^{*}$ & $45(24-85) *$ & $35(12-106) *$ & [55] & & & & \\
\hline & $93 \pm 17^{* *}$ & $3418 \pm 314 * *$ & na & [10] & $5.8 \pm 0.4^{* *}$ & $698 \pm 71 * *$ & na & [10] \\
\hline \multirow{3}{*}{ Methamphetamine } & $1.05(0.75-1.5) *$ & $>10 *$ & $>10 *$ & {$[9,67]$} & $1.56(0.9-2.8)^{*}$ & $>33^{*}$ & na & [9] \\
\hline & $1.1(0.7-1.7) *$ & $18(3-116) *$ & $17(1.8-166)^{*}$ & [64] & $0.435 \pm 0.075 *$ & $23.3 \pm 4.2^{*}$ & na & [55] \\
\hline & & & & & $8.5 \pm 1.4^{* *}$ & $1291 \pm 241.6^{* *}$ & $152.0 * *$ & [8] \\
\hline Ephedrine & $46(27-79) *$ & $230(72-735) *$ & $5.0(0.9-27) *$ & {$[64]$} & & & & \\
\hline \multirow{3}{*}{ MDMA } & $17(12-24)$ * & $1.36(1.0-2.0) *$ & $0.08(0.04-0.16) *$ & [9] & $22(8.9-53) *$ & $5.63(3.5-9.2) *$ & na & [9] \\
\hline & $31(8-118)$ * & $2.0(1.4-3.0)^{*}$ & $0.06(0.01-0.4) *$ & [64] & $7.5 \pm 2.3^{*}$ & $1.1 \pm 0.29^{*}$ & na & [55] \\
\hline & & & & & $51.2 \pm 6.3^{* *}$ & $49.6 \pm 5.4^{* *}$ & $0.97 * *$ & [8] \\
\hline MBDB & $22(20-26) *$ & $2.04(1.3-3.0) *$ & $0.09(0.05-0.15) *$ & [9] & $>100 *$ & $2.49(1.0-6.9) *$ & na & [9] \\
\hline MDEA & $9.3(8.0-11) *$ & $1.27(0.93-1.7)^{*}$ & $0.14(0.01-0.21) *$ & [9] & $>100 *$ & $2.88(1.6-5.0)^{*}$ & na & [9] \\
\hline Cocaine & $0.768(0.6-1.0) *$ & $2.37(2.0-2.9) *$ & $3.1(2.0-4.8) *$ & [9] & $>100 *$ & $>100 *$ & na & [9] \\
\hline
\end{tabular}

DAT = dopamine transporter; SERT $=$ serotonin transporter; na $=$ not reported by authors; DAT $/$ SERT ratio $=\left(\mathrm{DAT} \mathrm{IC}_{50}\right)^{-1} /\left(\mathrm{SERT} \mathrm{IC}_{50}\right)^{-1}$, $\mathrm{DAT} / \mathrm{SERT}$ ratio $=\left(\mathrm{DAT} \mathrm{EC}_{50}\right)^{-1} /\left(\mathrm{SERT} \mathrm{EC}_{50}\right)^{-1}$; values are expressed as mean or means $\pm \mathrm{SD}$, similar to original articles. The ability of tested drugs to inhibit the transport-mediated uptake is expressed as $\mathrm{IC}_{50}$. The ability of tested drugs to influence the transporter-mediated release is expressed as $\mathrm{EC}_{50} .{ }^{*}$ in vitro studies for neurotransmitter reuptake inhibition and release using HEK293 (Human Embryonic Kidney 293) cell line expressing DAT and SERT ( $\mathrm{IC}_{50}$ and $\mathrm{EC}_{50}$ values are expressed in $\left.\mu \mathrm{M}\right)$. ** in vitro studies for neurotransmitter reuptake inhibition and release from rat brain synaptosomes $\left(\mathrm{IC}_{50}\right.$ and $\mathrm{EC}_{50}$ values are expressed in $\left.\mathrm{nM}\right)$.

Activation of the central dopaminergic and serotonergic pathways by synthetic derivatives of cathinone and amphetamine derivatives may act as a trigger for acute psychotic reactions. These are common in consumers of "bath salts" who previously had a normal psychological profile. Given the illicit origin of most of the compounds, their synthesis takes place in clandestine laboratories. Consequently, the presence of impurities (e.g., manganese) [78-83], has been described and chronic exposure has additive, "impurity-related" toxicity. In addition, the "finished product" is often diluted with other psychotropic compounds (e.g., cannabinoids, ephedrine, caffeine, opioids, benzodiazepines, etc.). Consumption of such a mixture can lead to both acute poisoning and chronic exposure, both of which have a multifactorial etiology [84-87].

\subsection{Biochemical Mechanisms: Dopamine, Oxidative Stress, and Cytotoxicity}

Nowadays, the dependence and consumption of illegal drugs is a major social concern, not only in developing countries, because of medical complications in different organs (e.g., brain, heart, liver, and kidneys) [88]. This toxicity is studied from the perspective of a new 
approach, by evaluating the oxidative stress, manifested by macromolecular degradation, lipid peroxidation, functional incapacity and cell death by apoptosis [89].

The beneficial effects of a certain level of oxidative stress are undeniable given their involvement in the phagocytosis processes [90,91] and cell signaling [92]. At the same time, recent studies show that ROS play a key role in apoptosis [93], being part of the transduction signal during this process [94]. An abnormal production exceeds the endogenous antioxidant capacity ("damage control").

For obvious reasons, the brain is one of the organs highly affected by oxidative stress and despite the fact that it represents only $2 \%$ of the total body weight, it consumes about $20 \%$ of the inspired oxygen and generates an increased amount of free radicals. Moreover, cerebrospinal fluid contains transition metals like iron or copper that catalyze reactions in which free radicals are generated [95]. The mechanisms through which free radicals damage neuronal tissue are not exactly known, but it is commonly accepted that the permeability of the BBB and the normal morphology of the brain are affected [96].

Neurotransmitters, such as GLU or DA, are also involved in the generation of free radicals. For example, the GLU action on NMDA receptors produces an influx of calcium ions that activates nitric oxide synthase (NOS), and nitric oxide (NO) is a precursor of peroxynitrite. During enzymatic and non-enzymatic oxidation of DA, free radicals are generated in DA neurons from various areas of the brain, the most important of which is the nigrostriatal pathway, which projects from the substantia nigra to striatum, involved in Parkinson's disease and iatrogenic parkinsonism [97].

DA is an extremely important neurotransmitter in the CNS. It is released at the level of the reward system, especially in the NAc, being responsible for the well-being produced by euphoric substances. However, DA has other functions through dopaminergic pathways and neural connections through which this neurotransmitter reaches many areas of the CNS. The feeling of pleasure and reward induced by DA is controlled by mesolimbic dopaminergic pathways that start from the ventral tegmental area (VTA) located in the midbrain. From here, through the projections of DA neurons, the nerve impulse reaches the NAc, the place where DA produces these positive feelings, including the euphoria induced by psychoactive substances [98].

The mesocortical pathway also begins in the VTA, but, in this case, the projections of DA neurons reach the medial prefrontal cortex (mPFC) where they control cognition, decision-making and memory, especially working memory. This explains why certain psychoactive substances (e.g., amphetamines) increase, in the first phase, the capacity to work. Another dopaminergic pathway (the nigrostriatal pathway) controls involuntary movements and projects from the substantia nigra to striatum (caudate nucleus and putamen). However, DA also has endocrine effects through the tuberoinfundibular pathway from the hypothalamus (arcuate and periventricular nuclei). At this level, DA acts as a PIF (prolactin inhibitory factor) allowing negative control of the release of prolactin from the anterior pituitary gland [99].

For example, the concrete mechanism by which MPTP (1-methyl-4-phenyl-1,2,3,6tetrahydropyridine) exerts its selective toxic action on DA neurons and causes iatrogenic parkinsonism is only partially understood. MPTP, being a compound with a high lipid/water partition coefficient, readily crosses the BBB. Benefiting from an amphiphilic structure, it is taken up by astrocytic lysosomes [100] and oxidized to MPP+ (1-methyl-4phenylpyridinium) by MAO-B [101].

It is then preferentially captured by DA neurons via DAT. Here, MPP+ blocks the electron transport chain (ETC) by inhibiting complexes I and III. As a result, the amount of ATP decreases, the intracellular concentration of $\mathrm{Ca}^{2+}$ increases. ROS are generated in an autocatalytic manner and neuronal apoptosis is activated [102].

\subsection{Cathinone Derivatives}

Because of the strict legal regime of amphetamine-type drugs and MDMA [103], drug abusers turned to other substances that are easier to obtain, known as "bath salts" [104] 
among which is mephedrone, a compound with $\beta$-keto-amphetamine structure. Similar to amphetamine analogues, this substance acts at the cortical and striatal level, or on the NAc [105] by modulating DA and 5-HT transmission [106-111], inhibiting reuptake [8] and stimulating the release of monoamines from vesicles [112,113], as shown in Figure 3.

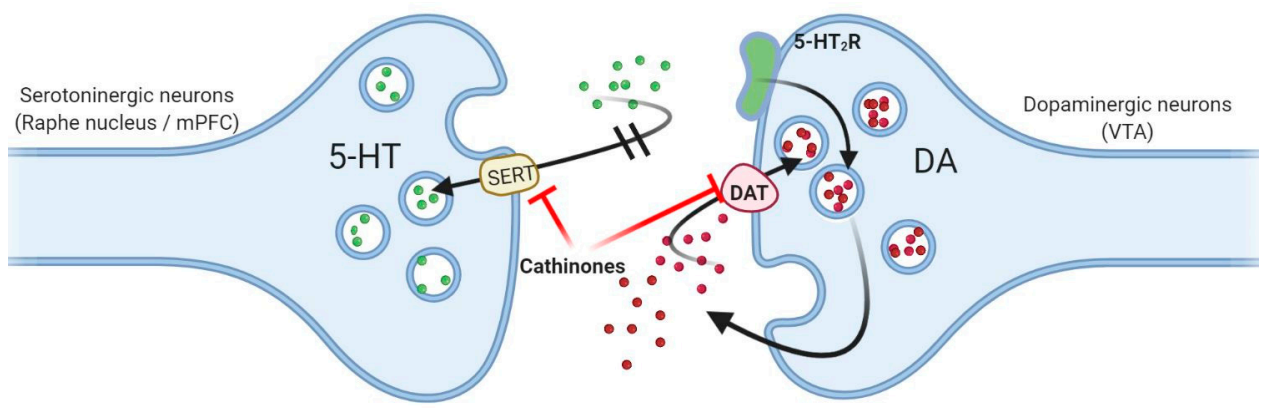

Figure 3. The general mechanisms proposed for promoting dopaminergic neurotransmission by cathinones. Cathinones inhibit the reuptake of serotonin (5-HT) and dopamine (DA) from the synaptic cleft by blocking the activity of transporters for 5-HT (SERT) and DA (DAT), and subsequently leading to accumulation of 5-HT which stimulates postsynaptic 5-HT $2 \mathrm{~A}$ receptors $\left(5-\mathrm{HT}_{2} \mathrm{R}\right)$ favoring the release of DA in the synaptic cleft (and which then remains at this level and cannot be recaptured). Created with BioRender.com (accessed on 22 January 2021).

Animal studies suggest that mephedrone stimulates motor functions and chronic use causes a progressive loss of 5-HT and DA neurons in the hippocampal and striatal area [111-113]. The cause of this massive damage of DA neurons has not been elucidated yet, but it has been hypothesized that oxidative stress caused by ROS and RNS could be a major contributor. The origin of these reactive species are the neurotransmitters, especially DA and the influence of psychoactive agents on the mitochondrial ETC [111,114-119]. In spite of antioxidant systems, free radicals accumulate causing immediate molecular damage (e.g., protein carbonylation, lipid peroxidation) [17] and degradation of cellular organs playing an important role in the development and progression of neurodegenerative diseases [111]. In adolescents, oxidative stress generated by abuse of psychoactive drugs affects both cortical neurons and transmission to subcortical structures, with consequences on cognitive function $[120,121]$. In general, the consumption of psychostimulant drugs exerts pro-oxidative effect and, in the hippocampus and prefrontal cortex [113], it decreases the total antioxidant capacity, the activity of antioxidant enzymes and it also increases the concentration of malondialdehyde (MDA) [122,123], as the brain contains considerable amounts of lipids and transition metals, resulting in alteration of interneuronal transmission [121,122]. Among the clinical manifestations, which appear after the consumption of substances with $\beta$-keto-amphetamine structure, are hypokinesia and dystonia, suggesting modifications of the extrapyramidal system, similar to Parkinson's disease [124], with the remark that the use of mephedrone does not produce tremor-at-rest [79]. A possible cause of these symptoms is the accumulation of manganese [125] used in the synthesis of the drug [126], in the internal globus pallidus [127], and in the pars compacta of substantia nigra [128], where it exerts various cytotoxic effects including generation of free radicals and apoptosis in the corpus striatum [129,130]. There is no antidote for manganese or mephedrone intoxication and the classic antiparkinsonian medications are not effective in this syndrome $[79,131]$.

\subsection{Amphetamine Derivatives}

In case of amphetamine and methamphetamine use, similar to mephedrone, the immediate effects are caused by interference with DA neuronal transmission [132]. These substances penetrate the neuron and cause a massive release of the neurotransmitter into the synaptic cleft. Studies in rodents show that amphetamines increase the levels of oxidative stress markers such as MDA, SOD, glutathione (GSH/GSSG), 2,3-dihydroxybenzoic 
acid in the cortex, corpus striatum [133], and hippocampus [134]. Moreover, toxic doses of methamphetamine inhibit the ETC, by interfering with all four complexes, in the corpus striatum, hippocampus, amygdala, nucleus caudatus, and prefrontal cortex, being incriminated in the development of neurodegenerative diseases [135-137]. Neuronal death in these areas occurs by apoptosis [138] as a consequence of the modified ratio between pro-apoptotic (Bax, Bad) and anti-apoptotic proteins (Bcl-2, Bcl-XL) resulting in the activation of caspases 9 and 3 [139,140]. Amphetamine and/or cocaine-induced neurotoxicity [141] is mediated by the glutamatergic system (Figure 4), by activation of NMDA receptors [139,142], following intracytoplasmic influx of $\mathrm{Ca}^{2+}[133,143,144]$ and activation of NOS. Following the increase in the concentration of NA in the synaptic cleft, there will be an increase in the concentration of GLU in mPFC neurons (the inhibition of the inhibitory control of neurotransmitter release by gamma-aminobutyric acid, GABA). This increase can be facilitated, for example, by inhibiting the reuptake of NA by cocaine. Consequently, NA activates $\alpha 1$ adrenergic receptors located in DA VTA neurons. This process promotes the release of 2-arachidonylglycerol (2-AR) into the synaptic cleft, thus activating the endogenous cannabinoid pathway. The lipid mediator acts on postsynaptic cannabinoid receptors (CB1R) preventing the release of GABA. Thus, the negative control is suspended and there will be an increased release of GLU [145]. Due to the activation of NOS following $\mathrm{Ca}^{2+}$ influx, the newly formed compound can generate free radicals, especially peroxynitrite [146], which interacts with the hydroxyl radical formed by the Haber-Weiss/Fenton reaction [137,147-149]. Besides the vasodilating effect following the activation of cGMP, $\mathrm{NO}$ can nitrosylate proteins that modulate the apoptotic process. One such protein is glyceraldehyde-3-phosphate dehydrogenase (GAPDH) which enters the nucleus in nitrosylated form and is able to interact with Siah1 [150] as shown in Figure 5.

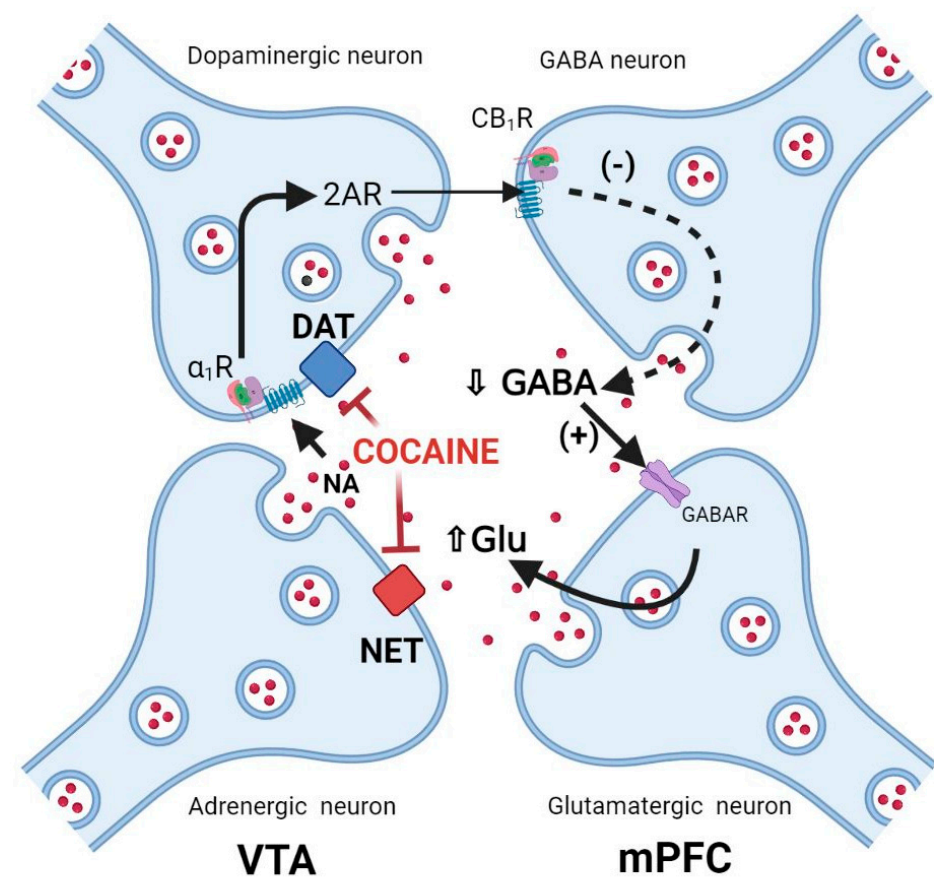

Figure 4. The proposed mechanism for promoting glutamatergic neurotransmission by cocainecocaine inhibits the reuptake of dopamine (DA) and norepinephrine (NA) due to the inhibition of specific dopamine transporter (DAT) and norepinephrine (NET) transporters in medial prefrontal cortex (mPFC). NA in the synaptic cleft stimulates $\alpha_{1}\left(\alpha_{1} R\right)$ receptors in DA neurons by promoting the release of endocannabinoids (2-arachidonoylglycerol, $2 \mathrm{AR}$ ) which, after binding to $\mathrm{CB}_{1} \mathrm{R}$ receptors, inhibit gamma-aminobutyric acid (GABA) release in the synaptic cleft. A lower concentration of GABA promotes the release of glutamate (GLU) due to the suppression of the inhibitory effect of GABA on the release of GLU. Created with BioRender.com (accessed on 22 January 2021). 


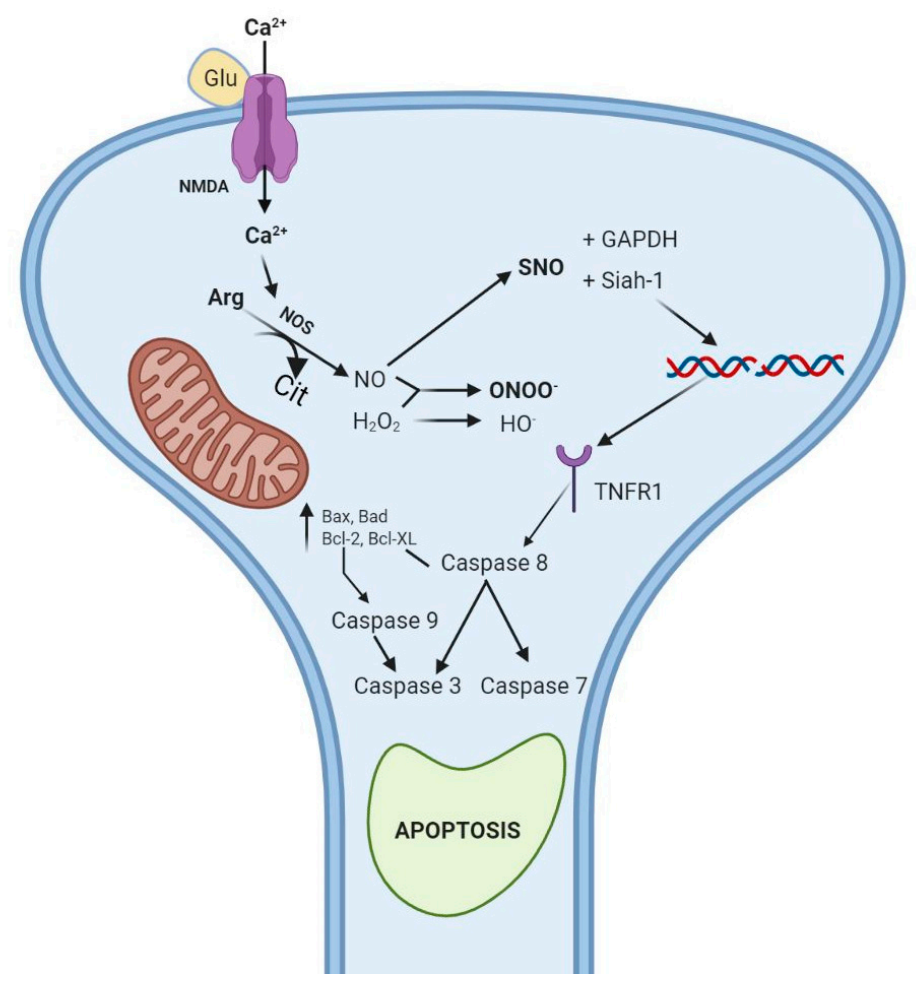

Figure 5. Glutamate (GLU) mediated neurotoxicity. GLU stimulates NMDA receptors by promoting the influx of intracellular $\mathrm{Ca}^{2+}$. Calcium increases nitric oxide-synthase (NOS) activity with increasing intracellular concentration of nitric oxide (NO). S-nitrosothiols (SNO) together with reactive oxygen species (ROS) resulting from the Haber Weiss/Fenton reaction, forms the ONOO- radical which after binding to glyceraldehyde-3-phosphate dehydrogenase (GAPDH) interacts with Siah1 the complex formed by stimulating the transition/translation process with tumor necrosis factor $\left(\mathrm{TNFR}_{1}\right)$ receptor overexpression at the cell surface. This favors the action of TNF $\alpha$ and the initiation of the apoptotic process. Created with BioRender.com (accessed on 22 January 2021).

This interaction is beneficial for Siah1 as it is protected from degradation and can initiate the apoptotic process $[134,151]$. Other studies support the idea that tyrosine nitration is an important factor in the development of neurodegenerative diseases [149] including Parkinson's disease [152]. Regarding free radicals, both ROS and RNS [153] are mediators of inflammation, but also the inflammatory process itself is a producer of ROS and RNS, thus increasing the susceptibility to neuronal degeneration, mediated by DA in the substantia nigra [154]. DA, uncontrollably released as a result of amphetamine abuse, is responsible for the excess of ROS. The main metabolization pathway of DA is via MAO-B, but another degradation pathway involves oxidation of the catechol nucleus, generating quinones and reactive species [155], as shown in Figure 6. These quinones can bind to cysteine thiol groups impairing normal protein functions [140]. 


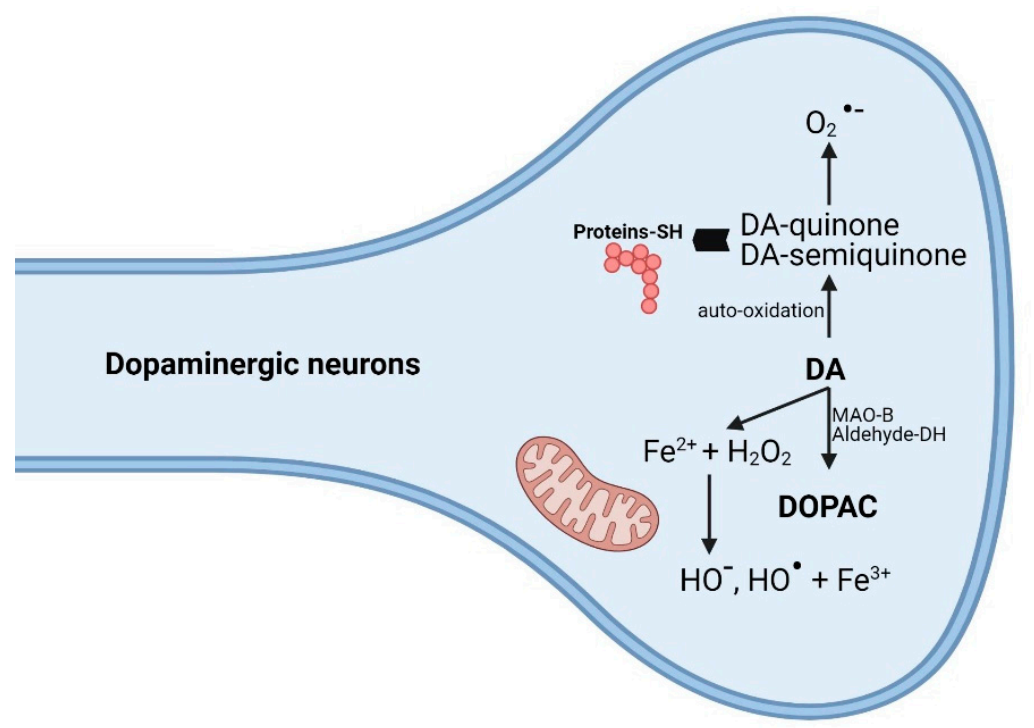

Figure 6. Toxic reactions of dopamine (DA) metabolites generated after oxidation. The neurotoxicity of DA is due to reactive oxygen species (ROS) produced as a result of monoamine oxidase (MAO) metabolism or as a result of an auto-oxidation process. 1. Under the action of MAO, 3,4dihydroxyphenylacetic acid (DOPAC), and $\mathrm{H}_{2} \mathrm{O}_{2}$ are later transformed into $\mathrm{ROS}\left(\mathrm{OH}^{-}, \mathrm{OH}^{\bullet}\right)$. within mitochondria. 2. The process of self-oxidation results in DA-quinones and DA-semiquinones which in turn generate $\mathrm{ROS}\left(\mathrm{O}_{2}{ }^{\bullet-}\right)$. These metabolites also interact with the-SH groups of proteins with toxic cellular action by altering the structure and/or function of protein. Created with BioRender.com (accessed on 22 January 2021).

\subsection{Cocaine}

The reason for cocaine induced neurotoxic effect is mainly derived from the mechanism of action, involving influencing neurotransmission by inhibiting mediator reuptake and inducing self-oxidation $[134,156]$ to which hypoxia caused by vasoconstriction is added. The neurotoxic effect is amplified by the increased activity of the nuclear factor kappa B (NF-kB) [157] conducting to high levels of pro-inflammatory cytokines and oxidases. Studies in rodents show increased levels of DA in the NAc [158] following decreased reuptake mechanisms.

High levels of peroxidated lipids and increased antioxidant enzymatic activity (GPx, SOD) [150] in certain areas of the brain, cortex and corpus striatum, were observed [149,159]. Following chronic cocaine use, GPx activity in the hippocampus is abolished $[137,160]$. The neuronal membrane is impermeable to GSH, consequently, the intervention of astrocytes is compulsory. They possess a transport mechanism ( $\mathrm{xc}^{-}$cystine/glutamate antiporter) involving a non-vesicular release of GLU outside neuron cells in exchange for cystine, which is supposed to be sensitive to free radicals generated by abusive drug use [161]. Degradation products [162] of cocaine, norcocaine, and nitrogen derivatives (nitroxide, nitrosonium) [158] have a much higher oxidizing potential, supported by determinations made on rodent brain tissue, the affected areas being the prefrontal cortex (PFC), corpus striatum, and the cerebellum $[158,163,164]$. An elevation of the nitrite level in the PFC and in the NAc is also observed $[165,166]$ as a consequence of increased NOS activity. It has been hypothesized that ROS are able to block DAT transporter leading to DA accumulation, which is oxidized and, consecutively, decreases the activity of antioxidant systems [167]. Moreover, the neuronal destruction occurring as a result of oxidative stress induced by cocaine abuse may increase the incidence of neurodegenerative diseases (Alzheimer's, Parkinson's) or psychiatric (schizophrenia, mania) ones [134,149,159]. An important argument to support this hypothesis comes from post-mortem determinations on the brain of cocaine abusers in which an increase in alpha-synuclein expression was observed as a result of DA neuron destruction [168]. The body synthesizes neurotrophins in order to protect 
neuronal tissue against the injuries caused by oxidative stress. Depending on the type of drug used, the expression Brain Derived Neurotrophic Factor (BDNF) differs, so that in methamphetamine and heroin abuse the BDNF level did not change compared with the control population. In MDMA and cocaine users, the concentration of neurotrophins increased but only for the initial period of abstinence, the values gradually returning to normal [169].

\subsection{Antioxidant Therapy Related to Drug Abuse}

This paragraph briefly discusses the antioxidant strategy for the drug-induced neurotoxicity presented in this review and possible pharmacological targets for treatment. It is expected that new, more effective and accessible therapies will be discussed in the near future [170].

The mechanism underlying the neurotoxicity induced by amphetamine derivatives is multifactorial, including the dysregulation of mitochondrial function, with a direct influence on neuronal energy balance and overproduction of ROS. In addition, the accumulation of DA in the synaptic cleft increases the sensitivity to oxidative stress and promotes the activation of apoptotic neuronal processes [170-172].

Thus, multiple in vivo and in vitro studies have been performed to discover compounds that reduce the production of ROS and RNS and also minimize neuronal degeneration. As follows, the antioxidant therapies used in these studies will be discussed.

One of the most commonly used antioxidants, ascorbic acid (vitamin C), has been shown to be beneficial in neurotoxicity that has arisen from the use of methamphetamine. In vitro, vitamin $C$ reduced ROS levels and regulated the activity of molecules involved in the apoptotic process $[173,174]$.

Other antioxidants used are tocopherols, especially alpha-tocopherol (vitamin E), which have the ability to protect the cell membrane against oxidative stress by stabilizing the phospholipidic bilayer against peroxidation. In addition, tocopherols have the ability to act against reactive species and thus reduce the level of MDA, generated as a result of lipid peroxidation $[175,176]$.

Dietary selenium supplementation provides antioxidant protection, reduces markers of oxidative stress and restores the optimal GSH/GSSG ratio, results which are supported by in vitro studies $[177,178]$. However, although selenium is an essential microelement, it has a narrow therapeutic index, the excess being incriminated in the occurrence of toxicity; therefore, selenium supplementation requires caution [179-181]. An alternative to the regulation of mitochondrial function is the administration of "mood stabilizers", such as lithium and valproic acid, as they are involved in the correction of the malfunction of the mitochondrial membrane, prevent the release cytochrome $\mathrm{c}$ and reduce the expression of proteins involved in the apoptotic process [182,183]. Further research to find substances that show the same tendency to decrease reactive species of nitrogen (RNS) [184] was conducted using neuronal nitric oxide synthase (nNOS) inhibitors, such as 7-nitroindazole (7-NI) [185,186], S-methylthiocitrulline or 3-bromo-7-nitroindazole [187]. The mechanism of action has not been fully elucidated and it is believed that neuroprotection is due to the ability to inhibit NO formation rather than involvement in thermoregulation, as methamphetamine induces hyperthermia [187].

Concerning the excitotoxicity induced by GLU by the facilitation of the intracellular influx of $\mathrm{Ca}^{2+}$, studies have been carried out using melatonin. This substance has protective properties against oxidative damage by regulating the intracellular level of $\mathrm{Ca}^{2+}[188,189]$.

$\mathrm{N}$-acetylcysteine exerts its protective effect after the use of methamphetamine [190-193]; the proposed mechanism is the regulation of the level of GSH [194] and the control of the concentration of GLU; it is regulated following stimulation of the antiport cystineglutamate [195]; regulation of the level of pro-inflammatory cytokines [196] also appears to be important. In addition, neuropeptide $\mathrm{Y}$ may have a protective role against neuronal apoptosis induced by methamphetamine via GLU [197]. 
New therapeutic approaches focus mainly on immunotherapy, aimed at reducing the amount of narcotic drugs that reach the CNS by synthesizing antibodies that bind to these illicit substances and limit their transfer and distribution [198,199]. However, there are some limitations given the fairly variable antibody titer [200] and the high costs [201].

The contribution of naturally occurring compounds to antioxidant therapy is a wellknown trend in research. Thus, a series of molecules of natural origin have been identified and highlighted, which seem very promising both in effect and safety such as epigallocatechin gallate (EGCG) [202], sulforaphane [203], 1-methyl-1,2,3,4-tetrahydroisoquinoline (1MeTIQ) [204], resveratrol [205], 7,8-dehydroxyflavone (7,8-DHF) [206,207].

A limitation of the mechanisms proposed for the antioxidant substances used as scavengers for free radicals or inhibitors of the formation of ROS/RNS is that a large part of the experiments are based on in vitro studies (e.g., ascorbic acid, selenium, lithium, valproate); only a few results are based on in vivo experiments on animal models (e.g., $\mathrm{N}$-acetylcysteine); this is why their relevance to clinical practice is uncertain (the evaluation of the effective dose in humans, transfer to the CNS, etc., still requires in-depth studies). The mentioned mechanisms proposed to explain the antioxidant action are highlighted in the Figure 7.

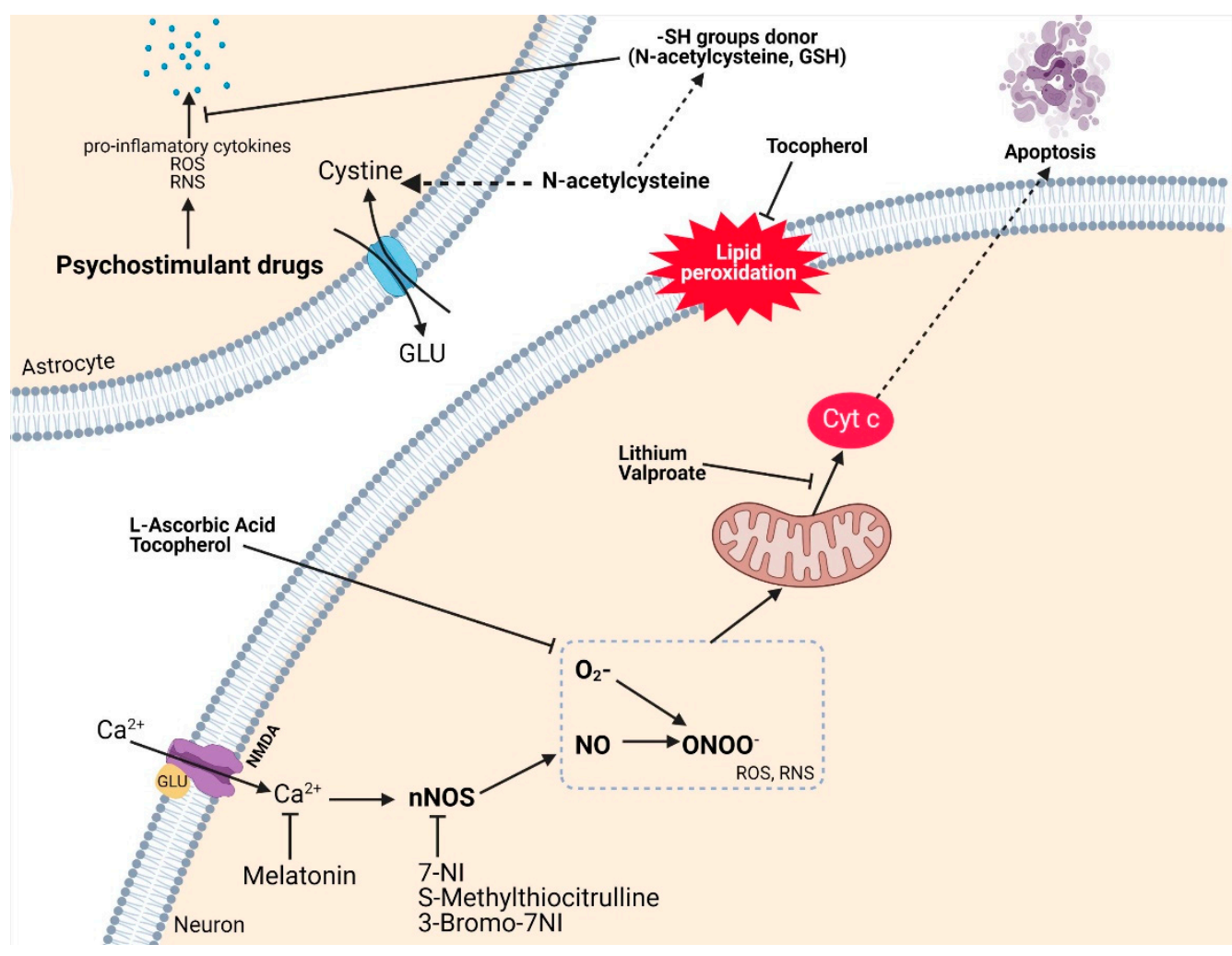

Figure 7. This illustration summarizes the proposed mechanism of antioxidant therapy in drug-related toxicity. Excessive stimulation of NMDA receptors by glutamate (GLU) generates numerous reactive oxygen (ROS) and/or nitrogen (RNS) species, subsequently leading to mitochondrial dysfunction, lipid peroxidation, and apoptosis. Thus, the use of compounds with antioxidant activity (e.g., L-ascorbic acid, tocopherol) reduces the oxidative status and preserves the integrity of the cell membrane. Lithium and valproic acid are involved in the correction of the malfunction of the mitochondrial membrane preventing the release of cytochrome $\mathrm{c}$ and reducing the expression of proteins involved in the apoptotic process. Neuronal nitric oxide synthase (nNOS) inhibitors limit the production of RNS. Melatonin protects against oxidative damage by regulating the intracellular level of $\mathrm{Ca}^{2+}$. N-acetylcysteine exerts its protective effect by regulating the level of GSH and controlling the concentration of GLU; following stimulation of the antiport cystine-glutamate and regulating the level of pro-inflammatory cytokines. Created with BioRender.com (accessed on 22 January 2021). 
Antioxidant therapy is a promising approach to target neuronal damage and facilitate neuroprotection and, in the future, it could be included in all medical conditions caracterized by oxidative stress, supposedly even those caused by the abuse of recreational drugs.

\section{Conclusions}

Regardless of the abused drug, the brain is the most susceptible and vulnerable organ to neurotoxic action caused by oxidative stress mostly because of the high content of transition metals and lipids. It has been observed that psychoactive agents consumed produce not only structural but also behavioral changes. An interesting topic would be the question of what causes neurodegeneration over time. Certainly, one of the factors involved in the brain and whole-body aging is oxidative stress associated with poor folding and aggregation of proteins and dysfunction of calcium channels correlated with GLU-induced excitotoxicity. One important research topic is the mechanism of neurodegenerative diseases in the context of drug addiction as one hypothesis states that these conditions are directly correlated with oxidative stress induced neuroinflammation. The molecular mechanism of different neurological conditions is unknown, but the association between free radicals, aging, and neurodegeneration is confirmed. Another important aspect is drug addiction as it has been demonstrated that it increases the level of free radicals. All of these mechanisms have, at least at some stage, one element in common, namely DA. This neurotransmitter is involved in the process of generating ROS and RNS directly, as a result of oxidation processes, or indirectly by promoting GLU neurotransmission. The chemical structure of psychoactive compounds explains the potency but also the tropism towards certain areas of the CNS. However, their ability to influence DA neurotransmission is different. Although the mechanisms of neurotoxicity produced by psychoactive substances are extremely complex and are not yet fully understood, these toxic effects could, in theory, be avoided with the aid of antioxidant therapy.

Author Contributions: Writing—original draft preparation, G.J.; writing—review and editing, G.J., B.E.Ö., C.E.V., and A.T.-V.; visualization, G.J., B.E.Ö., C.E.V., and A.T.-V.; funding acquisition, G.J. All authors have read and agreed to the published version of the manuscript.

Funding: This work was supported by the George Emil Palade University of Medicine, Pharmacy, Science, and Technology of Târgu Mureș, Research Grant number 293/4/14.01.2020.

Acknowledgments: The authors would like to thank Adrian Năznean for the English language revision of the manuscript.

Conflicts of Interest: The authors declare no financial or other conflict of interest.

\section{References}

1. Berman, S.; O’Neill, J.; Fears, S.; Bartzokis, G.; London, E.D. Abuse of Amphetamines and Structural Abnormalities in the Brain. Ann. N. Y. Acad. Sci. 2008, 1141, 195-220. [CrossRef]

2. Yamamoto, B.K.; Moszczynska, A.; Gudelsky, G.A. Amphetamine Toxicities: Classical and Emerging Mechanisms. Ann. N. Y. Acad. Sci. 2010, 1187, 101-121. [CrossRef]

3. Carvalho, M.; Carmo, H.; Costa, V.M.; Capela, J.P.; Pontes, H.; Remião, F.; Carvalho, F.; de Lourdes Bastos, M. Toxicity of Amphetamines: An Update. Arch. Toxicol. 2012, 86, 1167-1231. [CrossRef]

4. Valente, M.J.; Guedes de Pinho, P.; de Lourdes Bastos, M.; Carvalho, F.; Carvalho, M. Khat and Synthetic Cathinones: A Review. Arch. Toxicol. 2014, 88, 15-45. [CrossRef]

5. Prosser, J.M.; Nelson, L.S. The Toxicology of Bath Salts: A Review of Synthetic Cathinones. J. Med. Toxicol. 2012, 8, 33-42. [CrossRef] [PubMed]

6. Schreck, B.; Guerlais, M.; Laforgue, E.; Bichon, C.; Grall-Bronnec, M.; Victorri-Vigneau, C. Cathinone Use Disorder in the Context of Slam Practice: New Pharmacological and Clinical Challenges. Front. Psychiatry 2020, 11, 705. [CrossRef] [PubMed]

7. Martínez-Clemente, J.; Escubedo, E.; Pubill, D.; Camarasa, J. Interaction of Mephedrone with Dopamine and Serotonin Targets in Rats. Eur. Neuropsychopharmacol. 2012, 22, 231-236. [CrossRef]

8. Baumann, M.H.; Ayestas, M.A.; Partilla, J.S.; Sink, J.R.; Shulgin, A.T.; Daley, P.F.; Brandt, S.D.; Rothman, R.B.; Ruoho, A.E.; Cozzi, N.V. The Designer Methcathinone Analogs, Mephedrone and Methylone, Are Substrates for Monoamine Transporters in Brain Tissue. Neuropsychopharmacology 2012, 37, 1192-1203. [CrossRef] 
9. Simmler, L.; Buser, T.; Donzelli, M.; Schramm, Y.; Dieu, L.-H.; Huwyler, J.; Chaboz, S.; Hoener, M.; Liechti, M. Pharmacological Characterization of Designer Cathinones in Vitro: Pharmacology of Cathinones. Br. J. Pharmacol. 2013, 168, 458-470. [CrossRef] [PubMed]

10. Baumann, M.H.; Partilla, J.S.; Lehner, K.R.; Thorndike, E.B.; Hoffman, A.F.; Holy, M.; Rothman, R.B.; Goldberg, S.R.; Lupica, C.R.; Sitte, H.H.; et al. Powerful Cocaine-Like Actions of 3,4-Methylenedioxypyrovalerone (MDPV), a Principal Constituent of Psychoactive 'Bath Salts' Products. Neuropsychopharmacology 2013, 38, 552-562. [CrossRef]

11. López-Arnau, R.; Martínez-Clemente, J.; Pubill, D.; Escubedo, E.; Camarasa, J. Comparative Neuropharmacology of Three Psychostimulant Cathinone Derivatives: Butylone, Mephedrone and Methylone: Neuropharmacology of Cathinone Derivatives. Br. J. Pharmacol. 2012, 167, 407-420. [CrossRef]

12. Majchrzak, M.; Celiński, R.; Kuś, P.; Kowalska, T.; Sajewicz, M. The Newest Cathinone Derivatives as Designer Drugs: An Analytical and Toxicological Review. Forensic Toxicol. 2018, 36, 33-50. [CrossRef] [PubMed]

13. Drugs of Abuse, A DEA Resource Guide. 2020. Available online: https://youth.gov/federal-links/resource-drugs-abuse-dearesource-guide (accessed on 22 January 2021).

14. European Monitoring Centre for Drugs and Drug Addiction. European Drug Report: Trends and Developments; Publications Office of the European Union: Luxemburg, 2020. [CrossRef]

15. German, C.L.; Fleckenstein, A.E.; Hanson, G.R. Bath Salts and Synthetic Cathinones: An Emerging Designer Drug Phenomenon. Life Sci. 2014, 97, 2-8. [CrossRef] [PubMed]

16. Cunningham, K.A.; Callahan, P.M. Monoamine Reuptake Inhibitors Enhance the Discriminative State Induced by Cocaine in the Rat. Psychopharmacology 1991, 104, 177-180. [CrossRef] [PubMed]

17. Angoa-Pérez, M.; Anneken, J.H.; Kuhn, D.M. Neurotoxicology of Synthetic Cathinone Analogs. In Neuropharmacology of New Psychoactive Substances (NPS); Baumann, M.H., Glennon, R.A., Wiley, J.L., Eds.; Current Topics in Behavioral Neurosciences; Springer: Cham, Switzerland, 2016; Volume 32, pp. 209-230. [CrossRef]

18. Kousik, S.M.; Napier, T.C.; Carvey, P.M. The Effects of Psychostimulant Drugs on Blood Brain Barrier Function and Neuroinflammation. Front. Pharmacol. 2012, 3, 121. [CrossRef]

19. Steinkellner, T.; Montgomery, T.R.; Hofmaier, T.; Kudlacek, O.; Yang, J.-W.; Rickhag, M.; Jung, G.; Lubec, G.; Gether, U.; Freissmuth, M.; et al. Amphetamine Action at the Cocaine- and Antidepressant-Sensitive Serotonin Transporter Is Modulated by CaMKII. J. Neurosci. 2015, 35, 8258-8271. [CrossRef]

20. Fantegrossi, W.E.; Ciullo, J.R.; Wakabayashi, K.T.; De La Garza, R.; Traynor, J.R.; Woods, J.H. A Comparison of the Physiological, Behavioral, Neurochemical and Microglial Effects of Methamphetamine and 3,4-Methylenedioxymethamphetamine in the Mouse. Neuroscience 2008, 151, 533-543. [CrossRef]

21. Krasnova, I.N.; Justinova, Z.; Ladenheim, B.; Jayanthi, S.; McCoy, M.T.; Barnes, C.; Warner, J.E.; Goldberg, S.R.; Cadet, J.L. Methamphetamine Self-Administration Is Associated with Persistent Biochemical Alterations in Striatal and Cortical Dopaminergic Terminals in the Rat. PLoS ONE 2010, 5, e8790. [CrossRef]

22. Shaerzadeh, F.; Streit, W.J.; Heysieattalab, S.; Khoshbouei, H. Methamphetamine Neurotoxicity, Microglia, and Neuroinflammation. J. Neuroinflamm. 2018, 15, 341. [CrossRef]

23. Glennon, R.A.; Yousif, M.; Naiman, N.; Kalix, P. Methcathinone: A New and Potent Amphetamine-like Agent. Pharmacol. Biochem. Behav. 1987, 26, 547-551. [CrossRef]

24. Glennon, R.A.; Dukat, M. Structure-Activity Relationships of Synthetic Cathinones. In Neuropharmacology of New Psychoactive Substances (NPS); Baumann, M.H., Glennon, R.A., Wiley, J.L., Eds.; Current Topics in Behavioral Neurosciences; Springer: Cham, Switzerland, 2016; Volume 32, pp. 19-47. [CrossRef]

25. Kehr, J.; Ichinose, F.; Yoshitake, S.; Goiny, M.; Sievertsson, T.; Nyberg, F.; Yoshitake, T. Mephedrone, Compared with MDMA (Ecstasy) and Amphetamine, Rapidly Increases Both Dopamine and 5-HT Levels in Nucleus Accumbens of Awake Rats: Mephedrone Increases Both DA and 5-HT in Rat Brain. Br. J. Pharmacol. 2011, 164, 1949-1958. [CrossRef] [PubMed]

26. Wright, M.J.; Angrish, D.; Aarde, S.M.; Barlow, D.J.; Buczynski, M.W.; Creehan, K.M.; Vandewater, S.A.; Parsons, L.H.; Houseknecht, K.L.; Dickerson, T.J.; et al. Effect of Ambient Temperature on the Thermoregulatory and Locomotor Stimulant Effects of 4-Methylmethcathinone in Wistar and Sprague-Dawley Rats. PLoS ONE 2012, 7, e44652. [CrossRef] [PubMed]

27. Shortall, S.E.; Spicer, C.H.; Ebling, F.J.P.; Green, A.R.; Fone, K.C.F.; King, M.V. Contribution of Serotonin and Dopamine to Changes in Core Body Temperature and Locomotor Activity in Rats Following Repeated Administration of Mephedrone: Repeated Mephedrone Effects. Addict. Biol. 2016, 21, 1127-1139. [CrossRef]

28. Abdel-Salam, O.M.E.; Morsy, S.M.Y.; Youness, E.R.; Yassen, N.N.; Sleem, A.A. The Effect of Low Dose Amphetamine in Rotenone-Induced Toxicity in a Mice Model of Parkinson's Disease. Iran. J. Basic Med. Sci. 2020, 23, 1207. [CrossRef] [PubMed]

29. Baumann, M.H.; Solis, E.; Watterson, L.R.; Marusich, J.A.; Fantegrossi, W.E.; Wiley, J.L. Baths Salts, Spice, and Related Designer Drugs: The Science Behind the Headlines. J. Neurosci. 2014, 34, 15150-15158. [CrossRef]

30. Cameron, K.; Kolanos, R.; Verkariya, R.; De Felice, L.; Glennon, R.A. Mephedrone and Methylenedioxypyrovalerone (MDPV), Major Constituents of "Bath Salts," Produce Opposite Effects at the Human Dopamine Transporter. Psychopharmacology 2013, 227, 493-499. [CrossRef]

31. Naoi, M.; Maruyama, W. Cell Death of Dopamine Neurons in Aging and Parkinson's Disease. Mech. Ageing Dev. 1999, 111, 175-188. [CrossRef] 
32. Soto-Otero, R.; Munoz-Patino, A.M.; Labandeira-Garcia, J.L. Autoxidation and Neurotoxicity of 6-Hydroxydopamine in the Presence of Some Antioxidants: Potential Implication in Relation to the Pathogenesis of Parkinson's Disease. J. Neurochem. 2000, 74, 8. [CrossRef]

33. Miyazaki, I.; Asanuma, M. Approaches to Prevent Dopamine Quinone-Induced Neurotoxicity. Neurochem. Res. 2009, 34, 698-706. [CrossRef]

34. Trist, B.G.; Hare, D.J.; Double, K.L. Oxidative Stress in the Aging Substantia Nigra and the Etiology of Parkinson's Disease. Aging Cell 2019, 18, e13031. [CrossRef]

35. Huang, X.; Gu, H.H.; Zhan, C.-G. Mechanism for Cocaine Blocking the Transport of Dopamine: Insights from Molecular Modeling and Dynamics Simulations. J. Phys. Chem. B 2009, 113, 15057-15066. [CrossRef]

36. Cocaine and Amphetamine-like Psychostimulants: Neurocircuitry and Glutamate Neuroplasticity. Dialogues Clin. Neurosci. 2007, 9, 389-397. [CrossRef]

37. Robertson, S.D.; Matthies, H.J.G.; Galli, A. A Closer Look at Amphetamine-Induced Reverse Transport and Trafficking of the Dopamine and Norepinephrine Transporters. Mol. Neurobiol. 2009, 39, 73-80. [CrossRef]

38. Daberkow, D.P.; Brown, H.D.; Bunner, K.D.; Kraniotis, S.A.; Doellman, M.A.; Ragozzino, M.E.; Garris, P.A.; Roitman, M.F. Amphetamine Paradoxically Augments Exocytotic Dopamine Release and Phasic Dopamine Signals. J. Neurosci. 2013, 33, 452-463. [CrossRef]

39. Baumann, M.H.; Ayestas, M.A.; Sharpe, L.G.; Lewis, D.B.; Rice, K.C.; Rothman, R.B. Persistent Antagonism of MethamphetamineInduced Dopamine Release in Rats Pretreated with GBR12909 Decanoate. J. Pharmacol. Exp. Ther. 2002, 301, 1190-1197. [CrossRef]

40. Partilla, J.S.; Dempsey, A.G.; Nagpal, A.S.; Blough, B.E.; Baumann, M.H.; Rothman, R.B. Interaction of Amphetamines and Related Compounds at the Vesicular Monoamine Transporter. J. Pharmacol. Exp. Ther. 2006, 319, 237-246. [CrossRef] [PubMed]

41. Tucker, K.R.; Block, E.R.; Levitan, E.S. Action Potentials and Amphetamine Release Antipsychotic Drug from Dopamine Neuron Synaptic VMAT Vesicles. Proc. Natl. Acad. Sci. USA 2015, 112, E4485-E4494. [CrossRef] [PubMed]

42. Freyberg, Z.; Sonders, M.S.; Aguilar, J.I.; Hiranita, T.; Karam, C.S.; Flores, J.; Pizzo, A.B.; Zhang, Y.; Farino, Z.J.; Chen, A.; et al. Mechanisms of Amphetamine Action Illuminated through Optical Monitoring of Dopamine Synaptic Vesicles in Drosophila Brain. Nat. Commun. 2016, 7, 10652. [CrossRef] [PubMed]

43. Huotari, M.; García-Horsman, J.A.; Karayiorgou, M.; Gogos, J.A.; Männistö, P.T. D-Amphetamine Responses in Catechol-OMethyltransferase (COMT) Disrupted Mice. Psychopharmacology 2004, 172, 1-10. [CrossRef]

44. Liu, C.H.; Ren, J.; Liu, P.K. Amphetamine Manipulates Monoamine Oxidase-A Level and Behavior Using Theranostic Aptamers of Transcription Factors AP-1/NF-KB. J. Biomed. Sci. 2016, 23, 21. [CrossRef]

45. Reyes-Parada, M.; Iturriaga-Vasquez, P.; Cassels, B.K. Amphetamine Derivatives as Monoamine Oxidase Inhibitors. Front. Pharmacol. 2020, 10, 1590. [CrossRef]

46. Juárez Olguín, H.; Calderón Guzmán, D.; Hernández García, E.; Barragán Mejía, G. The Role of Dopamine and Its Dysfunction as a Consequence of Oxidative Stress. Oxid. Med. Cell. Longev. 2016, 2016, 1-13. [CrossRef] [PubMed]

47. Anneken, J.H.; Angoa-Pérez, M.; Kuhn, D.M. 3,4-Methylenedioxypyrovalerone Prevents While Methylone Enhances Methamphetamine-Induced Damage to Dopamine Nerve Endings: $\beta$-Ketoamphetamine Modulation of Neurotoxicity by the Dopamine Transporter. J. Neurochem. 2015, 133, 211-222. [CrossRef]

48. Martínez-Clemente, J.; López-Arnau, R.; Carbó, M.; Pubill, D.; Camarasa, J.; Escubedo, E. Mephedrone Pharmacokinetics after Intravenous and Oral Administration in Rats: Relation to Pharmacodynamics. Psychopharmacology 2013, 229, 295-306. [CrossRef]

49. Yan, Q.-S.; Reith, M.E.A.; Yan, S. Enhanced Accumbal Dopamine Release Following 5-HT2A Receptor Stimulation in Rats Pretreated with Intermittent Cocaine. Brain Res. 2000, 863, 254-258. [CrossRef]

50. Auclair, A.; Drouin, C.; Cotecchia, S.; Glowinski, J.; Tassin, J.-P. 5-HT2A and A1b-Adrenergic Receptors Entirely Mediate Dopamine Release, Locomotor Response and Behavioural Sensitization to Opiates and Psychostimulants: 5-HT2A and A1b-AR Mediate Behavioural Sensitization. Eur. J. Neurosci. 2004, 20, 3073-3084. [CrossRef]

51. Del Bello, F.; Sakloth, F.; Partilla, J.S.; Baumann, M.H.; Glennon, R.A. Ethylenedioxy Homologs of N-Methyl-(3,4Methylenedioxyphenyl)-2-Aminopropane (MDMA) and Its Corresponding Cathinone Analog Methylenedioxymethcathinone: Interactions with Transporters for Serotonin, Dopamine, and Norepinephrine. Bioorg. Med. Chem. 2015, 23, 5574-5579. [CrossRef]

52. Marusich, J.A.; Antonazzo, K.R.; Wiley, J.L.; Blough, B.E.; Partilla, J.S.; Baumann, M.H. Pharmacology of Novel Synthetic Stimulants Structurally Related to the "Bath Salts" Constituent 3,4-Methylenedioxypyrovalerone (MDPV). Neuropharmacology 2014, 87, 206-213. [CrossRef]

53. Meltzer, P.C.; Butler, D.; Deschamps, J.R.; Madras, B.K. 1-(4-Methylphenyl)-2-Pyrrolidin-1-Yl-Pentan-1-One (Pyrovalerone) Analogues: A Promising Class of Monoamine Uptake Inhibitors. J. Med. Chem. 2006, 49, 1420-1432. [CrossRef] [PubMed]

54. Eshleman, A.J.; Wolfrum, K.M.; Hatfield, M.G.; Johnson, R.A.; Murphy, K.V.; Janowsky, A. Substituted Methcathinones Differ in Transporter and Receptor Interactions. Biochem. Pharmacol. 2013, 85, 1803-1815. [CrossRef]

55. Eshleman, A.J.; Wolfrum, K.M.; Reed, J.F.; Kim, S.O.; Swanson, T.; Johnson, R.A.; Janowsky, A. Structure-Activity Relationships of Substituted Cathinones, with Transporter Binding, Uptake, and Release. J. Pharmacol. Exp. Ther. 2017, 360, 33-47. [CrossRef]

56. Baumann, M.H.; Walters, H.M.; Niello, M.; Sitte, H.H. Neuropharmacology of Synthetic Cathinones. In New Psychoactive Substances; Handbook of Experimental Pharmacology; Maurer, H.H., Brandt, S.D., Eds.; Springer: Cham, Switzerland, 2018; Volume 252, pp. 113-142. [CrossRef] 
57. Tyrkkö, E.; Pelander, A.; Ketola, R.A.; Ojanperä, I. In Silico and in Vitro Metabolism Studies Support Identification of Designer Drugs in Human Urine by Liquid Chromatography/Quadrupole-Time-of-Flight Mass Spectrometry. Anal. Bioanal. Chem. 2013, 405, 6697-6709. [CrossRef] [PubMed]

58. Sakloth, F.; Kolanos, R.; Mosier, P.D.; Bonano, J.S.; Banks, M.L.; Partilla, J.S.; Baumann, M.H.; Negus, S.S.; Glennon, R.A. Steric Parameters, Molecular Modeling and Hydropathic Interaction Analysis of the Pharmacology of Para-Substituted Methcathinone Analogues: Further QSAR of Para-Substituted Methcathinone Analogues. Br. J. Pharmacol. 2015, 172, 2210-2218. [CrossRef] [PubMed]

59. Swortwood, M.J.; Carlier, J.; Ellefsen, K.N.; Wohlfarth, A.; Diao, X.; Concheiro-Guisan, M.; Kronstrand, R.; Huestis, M.A. In Vitro, in Vivo and in Silico Metabolic Profiling of $\alpha$-Pyrrolidinopentiothiophenone, a Novel Thiophene Stimulant. Bioanalysis 2016, 8 , 65-82. [CrossRef]

60. Ellefsen, K.N.; Wohlfarth, A.; Swortwood, M.J.; Diao, X.; Concheiro, M.; Huestis, M.A. 4-Methoxy- $\alpha$-PVP: In Silico Prediction, Metabolic Stability, and Metabolite Identification by Human Hepatocyte Incubation and High-Resolution Mass Spectrometry. Forensic Toxicol. 2016, 34, 61-75. [CrossRef] [PubMed]

61. Niello, M.; Cintulova, D.; Hellsberg, E.; Jäntsch, K.; Holy, M.; Ayatollahi, L.H.; Cozzi, N.V.; Freissmuth, M.; Sandtner, W.; Ecker, G.F.; et al. Para-Trifluoromethyl-Methcathinone Is an Allosteric Modulator of the Serotonin Transporter. Neuropharmacology 2019, 161, 107615. [CrossRef]

62. Duart-Castells, L.; Nadal-Gratacós, N.; Muralter, M.; Puster, B.; Berzosa, X.; Estrada-Tejedor, R.; Niello, M.; Bhat, S.; Pubill, D.; Camarasa, J.; et al. Role of Amino Terminal Substitutions in the Pharmacological, Rewarding and Psychostimulant Profiles of Novel Synthetic Cathinones. Neuropharmacology 2021, 186, 108475. [CrossRef]

63. Negus, S.S.; Banks, M.L. Decoding the Structure of Abuse Potential for New Psychoactive Substances: Structure-Activity Relationships for Abuse-Related Effects of 4-Substituted Methcathinone Analogs. In Neuropharmacology of New Psychoactive Substances (NPS); Baumann, M.H., Glennon, R.A., Wiley, J.L., Eds.; Current Topics in Behavioral Neurosciences; Springer: Cham, Switzerland, 2016; Volume 32, pp. 119-131. [CrossRef]

64. Rickli, A.; Hoener, M.C.; Liechti, M.E. Monoamine Transporter and Receptor Interaction Profiles of Novel Psychoactive Substances: Para-Halogenated Amphetamines and Pyrovalerone Cathinones. Eur. Neuropsychopharmacol. 2015, 25, 365-376. [CrossRef]

65. Zwartsen, A.; Olijhoek, M.E.; Westerink, R.H.S.; Hondebrink, L. Hazard Characterization of Synthetic Cathinones Using Viability, Monoamine Reuptake, and Neuronal Activity Assays. Front. Neurosci. 2020, 14, 9. [CrossRef]

66. Luethi, D.; Kolaczynska, K.E.; Docci, L.; Krähenbühl, S.; Hoener, M.C.; Liechti, M.E. Pharmacological Profile of Mephedrone Analogs and Related New Psychoactive Substances. Neuropharmacology 2018, 134, 4-12. [CrossRef]

67. Simmler, L.D.; Rickli, A.; Hoener, M.C.; Liechti, M.E. Monoamine Transporter and Receptor Interaction Profiles of a New Series of Designer Cathinones. Neuropharmacology 2014, 79, 152-160. [CrossRef]

68. Saha, K.; Li, Y.; Holy, M.; Lehner, K.R.; Bukhari, M.O.; Partilla, J.S.; Sandtner, W.; Sitte, H.H.; Baumann, M.H. The Synthetic Cathinones, Butylone and Pentylone, Are Stimulants That Act as Dopamine Transporter Blockers but 5-HT Transporter Substrates. Psychopharmacology 2019, 236, 953-962. [CrossRef] [PubMed]

69. Saha, K.; Partilla, J.S.; Lehner, K.R.; Seddik, A.; Stockner, T.; Holy, M.; Sandtner, W.; Ecker, G.F.; Sitte, H.H.; Baumann, M.H. 'Second-Generation' Mephedrone Analogs, 4-MEC and 4-MePPP, Differentially Affect Monoamine Transporter Function. Neuropsychopharmacology 2015, 40, 1321-1331. [CrossRef]

70. Banks, M.L.; Worst, T.J.; Rusyniak, D.E.; Sprague, J.E. Synthetic Cathinones (“Bath Salts”). J. Emerg. Med. 2014, 46, 632-642. [CrossRef]

71. Meyer, J. 3,4-Methylenedioxymethamphetamine (MDMA): Current Perspectives. Subst. Abuse Rehabil. 2013, 4, 83-99. [CrossRef] [PubMed]

72. Kirkpatrick, M.G.; Lee, R.; Wardle, M.C.; Jacob, S.; de Wit, H. Effects of MDMA and Intranasal Oxytocin on Social and Emotional Processing. Neuropsychopharmacology 2014, 39, 1654-1663. [CrossRef]

73. Rothman, R.B.; Vu, N.; Partilla, J.S.; Roth, B.L.; Hufeisen, S.J.; Compton-Toth, B.A.; Birkes, J.; Young, R.; Glennon, R.A. In Vitro Characterization of Ephedrine-Related Stereoisomers at Biogenic Amine Transporters and the Receptorome Reveals Selective Actions as Norepinephrine Transporter Substrates. J. Pharmacol. Exp. Ther. 2003, 307, 138-145. [CrossRef]

74. Cozzi, N.V.; Brandt, S.D.; Daley, P.F.; Partilla, J.S.; Rothman, R.B.; Tulzer, A.; Sitte, H.H.; Baumann, M.H. Pharmacological Examination of Trifluoromethyl Ring-Substituted Methcathinone Analogs. Eur. J. Pharmacol. 2013, 699, 180-187. [CrossRef]

75. Puerta, E.; Aguirre, N. Methylenedioxymethamphetamine (MDMA, 'Ecstasy'): Neurodegeneration versus Neuromodulation. Pharmaceuticals 2011, 4, 992-1018. [CrossRef]

76. Haber, S.N.; Heilbronner, S.R. Translational Research in OCD: Circuitry and Mechanisms. Neuropsychopharmacology 2013, $38,252$. [CrossRef]

77. Parrott, A.C. Recreational Ecstasy/MDMA, the Serotonin Syndrome, and Serotonergic Neurotoxicity. Pharmacol. Biochem. Behav. 2002, 71, 837-844. [CrossRef]

78. de Bie, R.M.A.; Gladstone, R.M.; Strafella, A.P.; Ko, J.-H.; Lang, A.E. Manganese-Induced Parkinsonism Associated With Methcathinone (Ephedrone) Abuse. Arch. Neurol. 2007, 64, 886. [CrossRef]

79. Stepens, A.; Logina, I.; Liguts, V.; Aldiňš, P.; Ekšteina, I.; Platkājis, A.; Mārtinssone, I.; Tērauds, E.; Rozentāle, B.; Donaghy, M. A Parkinsonian Syndrome in Methcathinone Users and the Role of Manganese. N. Engl. J. Med. 2008, 358, 1009-1017. [CrossRef] 
80. Selikhova, M.; Fedoryshyn, L.; Matviyenko, Y.; Komnatska, I.; Kyrylchuk, M.; Krolicki, L.; Friedman, A.; Taylor, A.; Jäger, H.R.; Lees, A.; et al. Parkinsonism and Dystonia Caused by the Illicit Use of Ephedrone-A Longitudinal Study. Mov. Disord. 2008, 23, 2224-2231. [CrossRef]

81. Fudalej, S.; Kołodziejczyk, I.; Gajda, T.; Majkowska-Zwolińska, B.; Wojnar, M. Manganese-Induced Parkinsonism among Ephedrone Users and Drug Policy in Poland. J. Addict. Med. 2013, 7, 302-303. [CrossRef]

82. Debruyne, D.; Loilier, M.; Cesbron, A.; Le Boisselier, R.; Bourgine, J. Emerging Drugs of Abuse: Current Perspectives on Substituted Cathinones. Subst. Abuse Rehabil. 2014, 5, 37-52. [CrossRef]

83. Schifano, F.; Napoletano, F.; Arillotta, D.; Zangani, C.; Gilgar, L.; Guirguis, A.; Corkery, J.M.; Vento, A. The Clinical Challenges of Synthetic Cathinones. Br. J. Clin. Pharmacol. 2020, 86, 410-419. [CrossRef] [PubMed]

84. Tero-Vescan, A.; Vari, C.-E.; Imre, S.; Filip, C.; Hancu, G. Comparative Analysis by HPLC-UV and Capillary Electrophoresis of Dietary Supplements for Weight Loss. Farmacia 2016, 64, 699-705.

85. Collins, G.T.; Abbott, M.; Galindo, K.; Rush, E.L.; Rice, K.C.; France, C.P. Discriminative Stimulus Effects of Binary Drug Mixtures: Studies with Cocaine, MDPV, and Caffeine. J. Pharmacol. Exp. Ther. 2016, 359, 1-10. [CrossRef] [PubMed]

86. Guirguis, A.; Corkery, J.M.; Stair, J.L.; Kirton, S.B.; Zloh, M.; Schifano, F. Intended and Unintended Use of Cathinone Mixtures. Hum. Psychopharmacol. Clin. Exp. 2017, 32, e2598. [CrossRef]

87. Gannon, B.M.; Galindo, K.I.; Mesmin, M.P.; Rice, K.C.; Collins, G.T. Reinforcing Effects of Binary Mixtures of Common Bath Salt Constituents: Studies with 3,4-Methylenedioxypyrovalerone (MDPV), 3,4-Methylenedioxymethcathinone (Methylone), and Caffeine in Rats. Neuropsychopharmacology 2018, 43, 761-769. [CrossRef]

88. Schiavone, S.; Jaquet, V.; Trabace, L.; Krause, K.-H. Severe Life Stress and Oxidative Stress in the Brain: From Animal Models to Human Pathology. Antioxid. Redox Signal. 2013, 18, 1475-1490. [CrossRef] [PubMed]

89. Gu, Y.; Dee, C.M.; Shen, J. Interaction of Free Radicals, Matrix Metalloproteinases and Caveolin-1 Impacts Blood-Brain Barrier Permeability. Front. Biosci. 2011, 3, 1216-1231. [CrossRef]

90. Apel, K.; Hirt, H. REACTIVE OXYGEN SPECIES: Metabolism, Oxidative Stress, and Signal Transduction. Annu. Rev. Plant Biol. 2004, 55, 373-399. [CrossRef]

91. Pizzino, G.; Irrera, N.; Cucinotta, M.; Pallio, G.; Mannino, F.; Arcoraci, V.; Squadrito, F.; Altavilla, D.; Bitto, A. Oxidative Stress: Harms and Benefits for Human Health. Oxid. Med. Cell. Longev. 2017, 2017, 1-13. [CrossRef]

92. D'Autréaux, B.; Toledano, M.B. ROS as Signalling Molecules: Mechanisms That Generate Specificity in ROS Homeostasis. Nat. Rev. Mol. Cell Biol. 2007, 8, 813-824. [CrossRef]

93. Redza-Dutordoir, M.; Averill-Bates, D.A. Activation of Apoptosis Signalling Pathways by Reactive Oxygen Species. Biochim. Biophys. Acta BBA Mol. Cell Res. 2016, 1863, 2977-2992. [CrossRef]

94. Kannan, K.; Jain, S.K. Oxidative Stress and Apoptosis. Pathophisiology 2000, 7, 153-163. [CrossRef]

95. Kanti Das, T.; Wati, M.R.; Fatima-Shad, K. Oxidative Stress Gated by Fenton and Haber Weiss Reactions and Its Association with Alzheimer's Disease. Arch. Neurosci. 2014, 2, e60038. [CrossRef]

96. Pomierny-Chamioło, L.; Moniczewski, A.; Wydra, K.; Suder, A.; Filip, M. Oxidative Stress Biomarkers in Some Rat Brain Structures and Peripheral Organs Underwent Cocaine. Neurotox. Res. 2013, 23, 92-102. [CrossRef] [PubMed]

97. Sorce, S.; Krause, K.-H. NOX Enzymes in the Central Nervous System: From Signaling to Disease. Antioxid. Redox Signal. 2009, 11, 2481-2504. [CrossRef] [PubMed]

98. Berridge, K.C. Pleasure Systems in the Brain. Neuron 2015, 86, 646-664. [CrossRef] [PubMed]

99. Fitzgerald, P.; Dinan, T.G.; Psychopharmacol, J. Prolactin and Dopamine: What Is the Connection? A Review. J. Psyschopharmacol. 2008, 22, 12-19. [CrossRef]

100. Marchetti, B.; L’Episcopo, F.; Morale, M.C.; Tirolo, C.; Testa, N.; Caniglia, S.; Serapide, M.F.; Pluchino, S. Uncovering Novel Actors in Astrocyte-Neuron Crosstalk in Parkinson's Disease: The Wnt/ $\beta$-Catenin Signaling Cascade as the Common Final Pathway for Neuroprotection and Self-Repair. Eur. J. Neurosci. 2013, 37, 1550-1563. [CrossRef]

101. Meredith, G.E.; Rademacher, D.J. MPTP Mouse Models of Parkinson's Disease: An Update. J. Park. Dis. 2011, 1, 19-33. [CrossRef]

102. Paul, R.; Choudhury, A.; Kumar, S.; Giri, A.; Sandhir, R.; Borah, A. Cholesterol Contributes to Dopamine-Neuronal Loss in MPTP Mouse Model of Parkinson's Disease: Involvement of Mitochondrial Dysfunctions and Oxidative Stress. PLoS ONE 2017, 12, e0171285. [CrossRef]

103. Angoa-Pérez, M.; Kane, M.J.; Briggs, D.I.; Francescutti, D.M.; Sykes, C.E.; Shah, M.M.; Thomas, D.M.; Kuhn, D.M. Mephedrone Does Not Damage Dopamine Nerve Endings of the Striatum, but Enhances the Neurotoxicity of Methamphetamine, Amphetamine, and MDMA. J. Neurochem. 2013, 125, 102-110. [CrossRef]

104. Angoa-Pérez, M.; Kane, M.J.; Francescutti, D.M.; Sykes, K.E.; Shah, M.M.; Mohammed, A.M.; Thomas, D.M.; Kuhn, D.M. Mephedrone, an Abused Psychoactive Component of 'Bath Salts' and Methamphetamine Congener, Does Not Cause Neurotoxicity to Dopamine Nerve Endings of the Striatum: Mephedrone Does Not Cause DA Nerve Terminal Toxicity. J. Neurochem. 2012, 120, 1097-1107. [CrossRef]

105. Suyama, J.A.; Sakloth, F.; Kolanos, R.; Glennon, R.A.; Lazenka, M.F.; Negus, S.S.; Banks, M.L. Abuse-Related Neurochemical Effects of Para-Substituted Methcathinone Analogs in Rats: Microdialysis Studies of Nucleus Accumbens Dopamine and Serotonin. J. Pharmacol. Exp. Ther. 2015, 356, 182-190. [CrossRef] 
106. Hadlock, G.C.; Webb, K.M.; McFadden, L.M.; Chu, P.W.; Ellis, J.D.; Allen, S.C.; Andrenyak, D.M.; Vieira-Brock, P.L.; German, C.L.; Conrad, K.M.; et al. 4-Methylmethcathinone (Mephedrone): Neuropharmacological Effects of a Designer Stimulant of Abuse. J. Pharmacol. Exp. Ther. 2011, 339, 530-536. [CrossRef]

107. Motbey, C.P.; Karanges, E.; Li, K.M.; Wilkinson, S.; Winstock, A.R.; Ramsay, J.; Hicks, C.; Kendig, M.D.; Wyatt, N.; Callaghan, P.D.; et al. Mephedrone in Adolescent Rats: Residual Memory Impairment and Acute but Not Lasting 5-HT Depletion. PLoS ONE 2012, 7, e45473. [CrossRef]

108. den Hollander, B.; Rozov, S.; Linden, A.-M.; Uusi-Oukari, M.; Ojanperä, I.; Korpi, E.R. Long-Term Cognitive and Neurochemical Effects of "Bath Salt" Designer Drugs Methylone and Mephedrone. Pharmacol. Biochem. Behav. 2013, 103, 501-509. [CrossRef]

109. López-Arnau, R.; Martínez-Clemente, J.; Abad, S.; Pubill, D.; Camarasa, J.; Escubedo, E. Repeated Doses of Methylone, a New Drug of Abuse, Induce Changes in Serotonin and Dopamine Systems in the Mouse. Psychopharmacology 2014, 231, 3119-3129. [CrossRef]

110. Martínez-Clemente, J.; López-Arnau, R.; Abad, S.; Pubill, D.; Escubedo, E.; Camarasa, J. Dose and Time-Dependent Selective Neurotoxicity Induced by Mephedrone in Mice. PLoS ONE 2014, 9, e99002. [CrossRef] [PubMed]

111. López-Arnau, R.; Martínez-Clemente, J.; Rodrigo, T.; Pubill, D.; Camarasa, J.; Escubedo, E. Neuronal Changes and Oxidative Stress in Adolescent Rats after Repeated Exposure to Mephedrone. Toxicol. Appl. Pharmacol. 2015, 286, 27-35. [CrossRef] [PubMed]

112. Pantano, F.; Tittarelli, R.; Mannocchi, G.; Pacifici, R.; di Luca, A.; Busardò, F.P.; Marinelli, E. Neurotoxicity Induced by Mephedrone: An up-to-Date Review. Curr. Neuropharmacol. 2017, 15, 738-749. [CrossRef] [PubMed]

113. Kamińska, K.; Noworyta-Sokołowska, K.; Górska, A.; Rzemieniec, J.; Wnuk, A.; Wojtas, A.; Kreiner, G.; Kajta, M.; Gołembiowska, K. The Effects of Exposure to Mephedrone During Adolescence on Brain Neurotransmission and Neurotoxicity in Adult Rats. Neurotox. Res. 2018, 34, 525-537. [CrossRef]

114. Escubedo, E.; Chipana, C.; Pérez-Sánchez, M.; Camarasa, J.; Pubill, D. Methyllycaconitine Prevents Methamphetamine-Induced Effects in Mouse Striatum: Involvement of A7 Nicotinic Receptors. J. Pharmacol. Exp. Ther. 2005, 315, 658-667. [CrossRef]

115. Chipana, C.; García-Ratés, S.; Camarasa, J.; Pubill, D.; Escubedo, E. Different Oxidative Profile and Nicotinic Receptor Interaction of Amphetamine and 3,4-Methylenedioxy-Methamphetamine. Neurochem. Int. 2008, 52, 401-410. [CrossRef]

116. Potula, R.; Hawkins, B.J.; Cenna, J.M.; Fan, S.; Dykstra, H.; Ramirez, S.H.; Morsey, B.; Brodie, M.R.; Persidsky, Y. Methamphetamine Causes Mitrochondrial Oxidative Damage in Human T Lymphocytes Leading to Functional Impairment. J. Immunol. 2010, 185, 2867-2876. [CrossRef]

117. Leong, H.S.; Philp, M.; Simone, M.; Witting, P.K.; Fu, S. Synthetic Cathinones Induce Cell Death in Dopaminergic SH-SY5Y Cells via Stimulating Mitochondrial Dysfunction. Int. J. Mol. Sci. 2020, 21, 1370. [CrossRef]

118. Shin, E.-J.; Tran, H.-Q.; Nguyen, P.-T.; Jeong, J.H.; Nah, S.-Y.; Jang, C.-G.; Nabeshima, T.; Kim, H.-C. Role of Mitochondria in Methamphetamine-Induced Dopaminergic Neurotoxicity: Involvement in Oxidative Stress, Neuroinflammation, and ProApoptosis-A Review. Neurochem. Res. 2018, 43, 66-78. [CrossRef]

119. Dawson, T.M.; Dawson, V.L. Mitochondrial Mechanisms of Neuronal Cell Death: Potential Therapeutics. Annu. Rev. Pharmacol. Toxicol. 2017, 57, 437-454. [CrossRef]

120. Marvanova, M. Drug-Induced Cognitive Impairment: Effect of Cardiovascular Agents. Ment. Health Clin. 2016, 6, 201-206. [CrossRef]

121. Budzynska, B.; Boguszewska-Czubara, A.; Kruk-Slomka, M.; Kurzepa, J.; Biala, G. Mephedrone and Nicotine: Oxidative Stress and Behavioral Interactions in Animal Models. Neurochem. Res. 2015, 40, 1083-1093. [CrossRef]

122. Safhi, M.M.; Alam, M.F.; Hussain, S.; Hakeem Siddiqui, M.A.; Khuwaja, G.; Jubran Khardali, I.A.; Al-Sanosi, R.M.; Islam, F. Cathinone, an Active Principle of Catha Edulis, Accelerates Oxidative Stress in the Limbic Area of Swiss Albino Mice. J. Ethnopharmacol. 2014, 156, 102-106. [CrossRef]

123. Fitzmaurice, P.S.; Tong, J.; Yazdanpanah, M.; Liu, P.P.; Kalasinsky, K.S.; Kish, S.J. Levels of 4-Hydroxynonenal and Malondialdehyde Are Increased in Brain of Human Chronic Users of Methamphetamine. J. Pharmacol. Exp. Ther. 2006, 319, 703-709. [CrossRef]

124. Sikk, K.; Taba, P.; Haldre, S.; Bergquist, J.; Nyholm, D.; Zjablov, G.; Asser, T.; Aquilonius, S.-M. Irreversible Motor Impairment in Young Addicts? Ephedrone, Manganism or Both? Acta Neurol. Scand. 2007, 115, 385-389. [CrossRef]

125. Li, L.; Yang, X. The Essential Element Manganese, Oxidative Stress, and Metabolic Diseases: Links and Interactions. Oxid. Med. Cell. Longev. 2018, 2018, 1-11. [CrossRef] [PubMed]

126. Tormoehlen, L.M.; Kumar, N. Neurotoxicology: Five New Things. Neurol. Clin. Pract. 2012, 2, 301-310. [CrossRef] [PubMed]

127. Anderson, J.G.; Cooney, P.T.; Erikson, K.M. Inhibition of DAT Function Attenuates Manganese Accumulation in the Globus Pallidus. Environ. Toxicol. Pharmacol. 2007, 23, 179-184. [CrossRef]

128. Verina, T.; Kiihl, S.F.; Schneider, J.S.; Guilarte, T.R. Manganese Exposure Induces Microglia Activation and Dystrophy in the Substantia Nigra of Non-Human Primates. NeuroToxicology 2011, 32, 215-226. [CrossRef] [PubMed]

129. Stepens, A.; Stagg, C.J.; Platkājis, A.; Boudrias, M.-H.; Johansen-Berg, H.; Donaghy, M. White Matter Abnormalities in Methcathinone Abusers with an Extrapyramidal Syndrome. Brain 2010, 133, 3676-3684. [CrossRef] [PubMed]

130. Stepens, A.; Groma, V.; Skuja, S.; Platkājis, A.; Aldiňš, P.; Ekšteina, I.; Mārtiṇsone, I.; Bricis, R.; Donaghy, M. The Outcome of the Movement Disorder in Methcathinone Abusers: Clinical, MRI and Manganesemia Changes, and Neuropathology. Eur. J. Neurol. 2014, 21, 199-205. [CrossRef] 
131. Fasano, A. Methcathinone-Induced Parkinsonism Results from Permanent Brain Damage: A Message for the Masses. Eur. J. Neurol. 2014, 21, 181-182. [CrossRef]

132. Guilarte, T.R.; Burton, N.C.; McGlothan, J.L.; Verina, T.; Zhou, Y.; Alexander, M.; Pham, L.; Griswold, M.; Wong, D.F.; Syversen, T.; et al. Impairment of Nigrostriatal Dopamine Neurotransmission by Manganese Is Mediated by Pre-Synaptic Mechanism(s): Implications to Manganese-Induced Parkinsonism. J. Neurochem. 2008, 107, 1236-1247. [CrossRef] [PubMed]

133. Anneken, J.H.; Angoa-Perez, M.; Sati, G.C.; Crich, D.; Kuhn, D.M. Assessing the Role of Dopamine in the Differential Neurotoxicity Patterns of Methamphetamine, Mephedrone, Methcathinone and 4-Methylmethamphetamine. Neuropharmacology 2018, 134, 46-56. [CrossRef] [PubMed]

134. Frey, B.N.; Martins, M.R.; Petronilho, F.C.; Dal-Pizzol, F.; Quevedo, J.; Kapczinski, F. Increased Oxidative Stress after Repeated Amphetamine Exposure: Possible Relevance as a Model of Mania. Bipolar Disord. 2006, 8, 275-280. [CrossRef] [PubMed]

135. Granado, N.; Ares-Santos, S.; Oliva, I.; O'Shea, E.; Martin, E.D.; Colado, M.I.; Moratalla, R. Dopamine D2-Receptor Knockout Mice Are Protected against Dopaminergic Neurotoxicity Induced by Methamphetamine or MDMA. Neurobiol. Dis. 2011, 42, 391-403. [CrossRef] [PubMed]

136. Mirecki, A.; Fitzmaurice, P.; Ang, L.; Kalasinsky, K.S.; Peretti, F.J.; Aiken, S.S.; Wickham, D.J.; Sherwin, A.; Nobrega, J.N.; Forman, H.J.; et al. Brain Antioxidant Systems in Human Methamphetamine Users: Brain Oxidative Stress in Methamphetamine Users. J. Neurochem. 2004, 89, 1396-1408. [CrossRef]

137. Liang, H.-W.; Xia, Q.; Bruce, I.C. Reactive Oxygen Species Mediate the Neuroprotection Conferred by a Mitochondrial ATPSensitive Potassium Channel Opener during Ischemia in the Rat Hippocampal Slice. Brain Res. 2005, 1042, 169-175. [CrossRef]

138. Wu, H.; Che, X.; Zheng, Q.; Wu, A.; Pan, K.; Shao, A.; Wu, Q.; Zhang, J.; Hong, Y. Caspases: A Molecular Switch Node in the Crosstalk between Autophagy and Apoptosis. Int. J. Biol. Sci. 2014, 10, 1072-1083. [CrossRef]

139. Cadet, J.L.; Jayanthi, S.; Deng, X. Methamphetamine-Induced Neuronal Apoptosis Involves the Activation of Multiple Death Pathways. Review. Neurotox. Res. 2005, 8, 199-206. [CrossRef]

140. Gonçalves, J.; Baptista, S.; Silva, A.P. Psychostimulants and Brain Dysfunction: A Review of the Relevant Neurotoxic Effects Neuropharmacology 2014, 87, 135-149. [CrossRef]

141. Brown, J.M.; Yamamoto, B.K. Effects of Amphetamines on Mitochondrial Function: Role of Free Radicals and Oxidative Stress. Pharmacol. Ther. 2003, 99, 45-53. [CrossRef]

142. Suto, N.; Ecke, L.E.; You, Z.-B.; Wise, R.A. Extracellular Fluctuations of Dopamine and Glutamate in the Nucleus Accumbens Core and Shell Associated with Lever-Pressing during Cocaine Self-Administration, Extinction, and Yoked Cocaine Administration. Psychopharmacology 2010, 211, 267-275. [CrossRef] [PubMed]

143. Tseng, E.E.; Brock, M.V.; Lange, M.S.; Troncoso, J.C.; Blue, M.E.; Lowenstein, C.J.; Johnston, M.V.; Baumgartner, W.A. Glutamate Excitotoxicity Mediates Neuronal Apoptosis After Hypothermic Circulatory Arrest. Ann. Thorac. Surg. 2010, 89, 440-445. [CrossRef] [PubMed]

144. Wang, X.; Michaelis, E.K. Selective Neuronal Vulnerability to Oxidative Stress in the Brain. Front. Aging Neurosci. $2010,2,12$. [CrossRef] [PubMed]

145. Wang, H.; Treadway, T.; Covey, D.P.; Cheer, J.F.; Lupica, C.R. Cocaine-Induced Endocannabinoid Mobilization in the Ventral Tegmental Area. Cell Rep. 2015, 12, 1997-2008. [CrossRef]

146. Cadet, J.L.; Krasnova, I.N.; Jayanthi, S.; Lyles, J. Neurotoxicity of Substituted Amphetamines: Molecular and Cellular Mechanisms. Neurotox. Res. 2007, 11, 183-202. [CrossRef]

147. Pubill, D.; Chipana, C.; Camins, A.; Pallàs, M.; Camarasa, J.; Escubedo, E. Free Radical Production Induced by Methamphetamine in Rat Striatal Synaptosomes. Toxicol. Appl. Pharmacol. 2005, 204, 57-68. [CrossRef]

148. Frey, B.N.; Valvassori, S.S.; Gomes, K.M.; Martins, M.R.; Dal-Pizzol, F.; Kapczinski, F.; Quevedo, J. Increased Oxidative Stress in Submitochondrial Particles after Chronic Amphetamine Exposure. Brain Res. 2006, 1097, 224-229. [CrossRef]

149. Bashkatova, V.; Mathieu-Kia, A.-M.; Durand, C.; Penit-Soria, J. Neurochemical Changes and Neurotoxic Effects of an Acute Treatment with Sydnocarb, A Novel Psychostimulant: Comparison with d-Amphetamine. Ann. N. Y. Acad. Sci. 2006, 965, 180-192. [CrossRef] [PubMed]

150. Xu, R.; Serritella, A.V.; Sen, T.; Farook, J.M.; Sedlak, T.W.; Baraban, J.; Snyder, S.H.; Sen, N. Behavioral Effects of Cocaine Mediated by Nitric Oxide-GAPDH Transcriptional Signaling. Neuron 2013, 78, 623-630. [CrossRef]

151. Zhang, F.; Chen, L.; Liu, C.; Qiu, P.; Wang, A.; Li, L.; Wang, H. Up-Regulation of Protein Tyrosine Nitration in MethamphetamineInduced Neurotoxicity through DDAH/ADMA/NOS Pathway. Neurochem. Int. 2013, 62, 1055-1064. [CrossRef]

152. Tsang, A.H.K.; Chung, K.K.K. Oxidative and Nitrosative Stress in Parkinson's Disease. Biochim. Biophys. Acta BBA Mol. Basis Dis. 2009, 1792, 643-650. [CrossRef]

153. Cui, K.; Luo, X.; Xu, K.; Ven Murthy, M.R. Role of Oxidative Stress in Neurodegeneration: Recent Developments in Assay Methods for Oxidative Stress and Nutraceutical Antioxidants. Prog. Neuropsychopharmacol. Biol. Psychiatry 2004, 28, 771-799. [CrossRef]

154. Yamamoto, B.K.; Raudensky, J. The Role of Oxidative Stress, Metabolic Compromise, and Inflammation in Neuronal Injury Produced by Amphetamine-Related Drugs of Abuse. J. Neuroimmune Pharmacol. 2008, 3, 203-217. [CrossRef]

155. Berman, S.B.; Hastings, T.G. Dopamine Oxidation Alters Mitochondrial Respiration and Induces Permeability Transition in Brain Mitochondria: Implications for Parkinson's Disease. J. Neurochem. 2001, 73, 1127-1137. [CrossRef] 
156. Pereira, R.B.; Andrade, P.B.; Valentão, P. A Comprehensive View of the Neurotoxicity Mechanisms of Cocaine and Ethanol. Neurotox. Res. 2015, 28, 253-267. [CrossRef]

157. Muriach, M.; López-Pedrajas, R.; Barcia, J.M.; Sanchez-Villarejo, M.V.; Almansa, I.; Romero, F.J. Cocaine Causes Memory and Learning Impairments in Rats: Involvement of Nuclear Factor Kappa B and Oxidative Stress, and Prevention by Topiramate: Topiramate Effects on Cocaine Administration. J. Neurochem. 2010, 114, 675-684. [CrossRef]

158. Kovacic, P. Role of Oxidative Metabolites of Cocaine in Toxicity and Addiction: Oxidative Stress and Electron Transfer. Med. Hypotheses 2005, 64, 350-356. [CrossRef] [PubMed]

159. Öztezcan, S.; Doğru-Abbasoğlu, S.; Mutlu-Türkoğlu, Ü.; Calay, Z.; Aykaç-Toker, G.; Uysal, M. The Role of Stimulated Lipid Peroxidation and Impaired Calcium Sequestration in the Enhancement of Cocaine Induced Hepatotoxicity by Ethanol. Drug Alcohol Depend. 2000, 58, 77-83. [CrossRef]

160. Poon, H.F.; Abdullah, L.; Mullan, M.A.; Mullan, M.J.; Crawford, F.C. Cocaine-Induced Oxidative Stress Precedes Cell Death in Human Neuronal Progenitor Cells. Neurochem. Int. 2007, 50, 69-73. [CrossRef] [PubMed]

161. Uys, J.D. Cocaine-Induced Adaptations in Cellular Redox Balance Contributes to Enduring Behavioral Plasticity. Neuropsychopharmacology 2011, 36, 2551-2560. [CrossRef] [PubMed]

162. Banerjee, S.; Ghosh, J.; Sil, P. Drug Metabolism and Oxidative Stress: Cellular Mechanism and New Therapeutic Insights. Biochem. Anal. Biochem. 2016, 5, 255. [CrossRef]

163. López-Pedrajas, R.; Ramírez-Lamelas, D.T.; Muriach, B.; Sánchez-Villarejo, M.V.; Almansa, I.; Vidal-Gil, L.; Romero, F.J.; Barcia, J.M.; Muriach, M. Cocaine Promotes Oxidative Stress and Microglial-Macrophage Activation in Rat Cerebellum. Front. Cell. Neurosci. 2015, 9, 279. [CrossRef]

164. Beiser, T.; Yaka, R. The Role of Oxidative Stress in Cocaine Addiction. J. Neurol. Neuromed. 2019, 4, 17-21. [CrossRef]

165. Macêdo, D.S.; de Vasconcelos, S.M.M.; dos Santos, R.S.; Aguiar, L.M.V.; Lima, V.T.M.; Viana, G.S.B.; de Sousa, F.C.F. Cocaine Alters Catalase Activity in Prefrontal Cortex and Striatum of Mice. Neurosci. Lett. 2005, 387, 53-56. [CrossRef]

166. Jang, E.Y.; Yang, C.H.; Hedges, D.M.; Kim, S.P.; Lee, J.Y.; Ekins, T.G.; Garcia, B.T.; Kim, H.Y.; Nelson, A.C.; Kim, N.J.; et al. The Role of Reactive Oxygen Species in Methamphetamine Self-Administration and Dopamine Release in the Nucleus Accumbens: ROS in METH-Taking Behavior. Addict. Biol. 2017, 22, 1304-1315. [CrossRef]

167. Walker, J.; Winhusen, T.; Storkson, J.M.; Lewis, D.; Pariza, M.W.; Somoza, E.; Somoza, V. Total Antioxidant Capacity Is Significantly Lower in Cocaine-Dependent and Methamphetamine-Dependent Patients Relative to Normal Controls: Results from a Preliminary Study: Oxidative stress and stimulant dependence. Hum. Psychopharmacol. Clin. Exp. 2014, $29,537-543$. [CrossRef]

168. Little, K.Y.; Ramssen, E.; Welchko, R.; Volberg, V.; Roland, C.J.; Cassin, B. Decreased Brain Dopamine Cell Numbers in Human Cocaine Users. Psychiatry Res. 2009, 168, 173-180. [CrossRef]

169. Sordi, A.O.; Pechansky, F.; Kessler, F.H.P.; Kapczinski, F.; Pfaffenseller, B.; Gubert, C.; de Aguiar, B.W.; de Magalhães Narvaez, J.C.; Ornell, F.; von Diemen, L. Oxidative Stress and BDNF as Possible Markers for the Severity of Crack Cocaine Use in Early Withdrawal. Psychopharmacology 2014, 231, 4031-4039. [CrossRef]

170. Berríos-Cárcamo, P.; Quezada, M.; Quintanilla, M.E.; Morales, P.; Ezquer, M.; Herrera-Marschitz, M.; Israel, Y.; Ezquer, F. Oxidative Stress and Neuroinflammation as a Pivot in Drug Abuse. A Focus on the Therapeutic Potential of Antioxidant and Anti-Inflammatory Agents and Biomolecules. Antioxidants 2020, 9, 830. [CrossRef] [PubMed]

171. Thrash-Williams, B.; Karuppagounder, S.S.; Bhattacharya, D.; Ahuja, M.; Suppiramaniam, V.; Dhanasekaran, M. MethamphetamineInduced Dopaminergic Toxicity Prevented Owing to the Neuroprotective Effects of Salicylic Acid. Life Sci. 2016, 154, 24-29. [CrossRef] [PubMed]

172. Nguyen, X.-K.T.; Lee, J.; Shin, E.-J.; Dang, D.-K.; Jeong, J.H.; Nguyen, T.-T.L.; Nam, Y.; Cho, H.-J.; Lee, J.-C.; Park, D.H.; et al. Liposomal Melatonin Rescues Methamphetamine-Elicited Mitochondrial Burdens, pro-Apoptosis, and Dopaminergic Degeneration through the Inhibition PKC $\delta$ Gene. J. Pineal Res. 2015, 58, 86-106. [CrossRef]

173. Huang, Y.-N.; Wang, J.-Y.; Lee, C.-T.; Lin, C.-H.; Lai, C.-C.; Wang, J.-Y. L-Ascorbate Attenuates Methamphetamine Neurotoxicity through Enhancing the Induction of Endogenous Heme Oxygenase-1. Toxicol. Appl. Pharmacol. 2012, 265, 241-252. [CrossRef]

174. Huang, Y.-N.; Yang, L.-Y.; Wang, J.-Y.; Lai, C.-C.; Chiu, C.-T.; Wang, J.-Y. L-Ascorbate Protects Against Methamphetamine-Induced Neurotoxicity of Cortical Cells via Inhibiting Oxidative Stress, Autophagy, and Apoptosis. Mol. Neurobiol. 2017, 54, 125-136. [CrossRef] [PubMed]

175. Perera, J.; Tan, J.; Jeevathayaparan, S.; Chakravarthi, S.; Haleagrahara, N. Neuroprotective Effects of Alpha Lipoic Acid on Haloperidol-Induced Oxidative Stress in the Rat Brain. Cell Biosci. 2011, 1, 12. [CrossRef] [PubMed]

176. Moszczynska, A.; Yamamoto, B.K. Methamphetamine Oxidatively Damages Parkin and Decreases the Activity of 26S Proteasome in Vivo: Methamphetamine and Ubiquitin-Proteasome System. J. Neurochem. 2011, 116, 1005-1017. [CrossRef] [PubMed]

177. Imam, S.Z.; Newport, G.D.; Islam, F.; Slikker, W.; Ali, S.F. Selenium, an Antioxidant, Protects against Methamphetamine-Induced Dopaminergic Neurotoxicity. Brain Res. 1999, 818, 575-578. [CrossRef]

178. Barayuga, S.M.; Pang, X.; Andres, M.A.; Panee, J.; Bellinger, F.P. Methamphetamine Decreases Levels of Glutathione Peroxidases 1 and 4 in SH-SY5Y Neuronal Cells: Protective Effects of Selenium. NeuroToxicology 2013, 37, 240-246. [CrossRef]

179. Ungvári, É.; Monori, I.; Megyeri, A.; Csiki, Z.; Prokisch, J.; Sztrik, A.; Jávor, A.; Benkő, I. Protective Effects of Meat from Lambs on Selenium Nanoparticle Supplemented Diet in a Mouse Model of Polycyclic Aromatic Hydrocarbon-Induced Immunotoxicity. Food Chem. Toxicol. 2014, 64, 298-306. [CrossRef] 
180. Ghosh, P.; Bhattacharjee, A.; Basu, A.; Singha Roy, S.; Bhattacharya, S. Attenuation of Cyclophosphamide-Induced Pulmonary Toxicity in Swiss Albino Mice by Naphthalimide-Based Organoselenium Compound 2-(5-Selenocyanatopentyl)-Benzo[de]Isoquinoline 1,3-Dione. Pharm. Biol. 2015, 53, 524-532. [CrossRef]

181. Kiełczykowska, M.; Kocot, J.; Paździor, M.; Musik, I. Selenium-A Fascinating Antioxidant of Protective Properties. Adv. Clin. Exp. Med. 2018, 27, 245-255. [CrossRef]

182. Bachmann, R.F.; Wang, Y.; Yuan, P.; Zhou, R.; Li, X.; Alesci, S.; Du, J.; Manji, H.K. Common Effects of Lithium and Valproate on Mitochondrial Functions: Protection against Methamphetamine-Induced Mitochondrial Damage. Int. J. Neuropsychopharmacol. 2009, 12, 805. [CrossRef]

183. Feier, G.; Valvassori, S.S.; Varela, R.B.; Resende, W.R.; Bavaresco, D.V.; Morais, M.O.; Scaini, G.; Andersen, M.L.; Streck, E.L.; Quevedo, J. Lithium and Valproate Modulate Energy Metabolism in an Animal Model of Mania Induced by Methamphetamine. Pharmacol. Biochem. Behav. 2013, 103, 589-596. [CrossRef]

184. Imam, S.Z.; Islam, F.; Itzhak, Y.; Slikker, W.; Ali, S.F. Prevention of Dopaminergic Neurotoxicity by Targeting Nitric Oxide and Peroxynitrite: Implications for the Prevention of Methamphetamine-Induced Neurotoxic Damage. Ann. N. Y. Acad. Sci. 2000, 914, 157-171. [CrossRef]

185. Di Monte, D.A.; Royland, J.E.; Jakowec, M.W.; Langston, J.W. Role of Nitric Oxide in Methamphetamine Neurotoxicity: Protection by 7-Nitroindazole, an Inhibitor of Neuronal Nitric Oxide Synthase. J. Neurochem. 2002, 67, 2443-2450. [CrossRef]

186. Virmani, A.; Gaetani, F.; Imam, S.; Binienda, Z.; Ali, S. Possible Mechanism for the Neuroprotective Effects of L-Carnitine on Methamphetamine-Evoked Neurotoxicity. Ann. N. Y. Acad. Sci. 2003, 993, 197-207. [CrossRef]

187. Itzhak, Y.; Martin, J.L.; Ali, S.F. NNOS Inhibitors Attenuate Methamphetamine-Induced Dopaminergic Neurotoxicity but Not Hyperthermia in Mice. NeuroReport 2000, 11, 2943-2946. [CrossRef]

188. Suwanjang, W.; Abramov, A.Y.; Charngkaew, K.; Govitrapong, P.; Chetsawang, B. Melatonin Prevents Cytosolic Calcium Overload, Mitochondrial Damage and Cell Death Due to Toxically High Doses of Dexamethasone-Induced Oxidative Stress in Human Neuroblastoma SH-SY5Y Cells. Neurochem. Int. 2016, 97, 34-41. [CrossRef] [PubMed]

189. Xu, S.; Pi, H.; Zhang, L.; Zhang, N.; Li, Y.; Zhang, H.; Tang, J.; Li, H.; Feng, M.; Deng, P.; et al. Melatonin Prevents Abnormal Mitochondrial Dynamics Resulting from the Neurotoxicity of Cadmium by Blocking Calcium-Dependent Translocation of Drp1 to the Mitochondria. J. Pineal Res. 2016, 60, 291-302. [CrossRef]

190. Hashimoto, K.; Tsukada, H.; Nishiyama, S.; Fukumoto, D.; Kakiuchi, T.; Shimizu, E.; Iyo, M. Protective Effects of N-Acetyl-LCysteine on the Reduction of Dopamine Transporters in the Striatum of Monkeys Treated with Methamphetamine. Neuropsychopharmacology 2004, 29, 2018-2023. [CrossRef]

191. Zhang, X.; Banerjee, A.; Banks, W.A.; Ercal, N. N-Acetylcysteine Amide Protects against Methamphetamine-Induced Oxidative Stress and Neurotoxicity in Immortalized Human Brain Endothelial Cells. Brain Res. 2009, 1275, 87-95. [CrossRef]

192. Grant, J.E.; Odlaug, B.L.; Kim, S.W. A Double-Blind, Placebo-Controlled Study of N-Acetyl Cysteine plus Naltrexone for Methamphetamine Dependence. Eur. Neuropsychopharmacol. 2010, 20, 823-828. [CrossRef] [PubMed]

193. Zhang, X.; Tobwala, S.; Ercal, N. N -Acetylcysteine Amide Protects against Methamphetamine-Induced Tissue Damage in CD-1 Mice. Hum. Exp. Toxicol. 2012, 31, 931-944. [CrossRef]

194. Chandramani Shivalingappa, P.; Jin, H.; Anantharam, V.; Kanthasamy, A.; Kanthasamy, A. N-Acetyl Cysteine Protects against Methamphetamine-Induced Dopaminergic Neurodegeneration via Modulation of Redox Status and Autophagy in Dopaminergic Cells. Parkinson's Dis. 2012, 2012, 1-11. [CrossRef]

195. McKetin, R.; Dean, O.M.; Baker, A.L.; Carter, G.; Turner, A.; Kelly, P.J.; Berk, M. A Potential Role for N-Acetylcysteine in the Management of Methamphetamine Dependence: N-Acetylcysteine for Methamphetamine. Drug Alcohol Rev. 2017, 36, 153-159. [CrossRef]

196. Fukami, G.; Hashimoto, K.; Koike, K.; Okamura, N.; Shimizu, E.; Iyo, M. Effect of Antioxidant N-Acetyl-1-Cysteine on Behavioral Changes and Neurotoxicity in Rats after Administration of Methamphetamine. Brain Res. 2004, 1016, 90-95. [CrossRef] [PubMed]

197. Baptista, S.; Bento, A.R.; Gonçalves, J.; Bernardino, L.; Summavielle, T.; Lobo, A.; Fontes-Ribeiro, C.; Malva, J.O.; Agasse, F.; Silva, A.P. Neuropeptide Y Promotes Neurogenesis and Protection against Methamphetamine-Induced Toxicity in Mouse Dentate Gyrus-Derived Neurosphere Cultures. Neuropharmacology 2012, 62, 2413-2423. [CrossRef] [PubMed]

198. Miller, M.L.; Moreno, A.Y.; Aarde, S.M.; Creehan, K.M.; Vandewater, S.A.; Vaillancourt, B.D.; Wright, M.J.; Janda, K.D.; Taffe, M.A. A Methamphetamine Vaccine Attenuates Methamphetamine-Induced Disruptions in Thermoregulation and Activity in Rats. Biol. Psychiatry 2013, 73, 721-728. [CrossRef] [PubMed]

199. Hambuchen, M.D.; Carroll, F.I.; Rüedi-Bettschen, D.; Hendrickson, H.P.; Hennings, L.J.; Blough, B.E.; Brieaddy, L.E.; Pidaparthi, R.R.; Owens, S.M. Combining Active Immunization with Monoclonal Antibody Therapy To Facilitate Early Initiation of a Long-Acting Anti-Methamphetamine Antibody Response. J. Med. Chem. 2015, 58, 4665-4677. [CrossRef]

200. Baracz, S.J.; Cornish, J.L. The Neurocircuitry Involved in Oxytocin Modulation of Methamphetamine Addiction. Front. Neuroendocrinol. 2016, 43, 1-18. [CrossRef] [PubMed]

201. Chen, Y.-H.; Wu, K.-L.; Tsai, H.-M.; Chen, C.-H. Treatment of Methamphetamine Abuse: An Antibody-Based Immunotherapy Approach. J. Food Drug Anal. 2013, 21, S82-S86. [CrossRef]

202. Pan, A.L.; Hasalliu, E.; Hasalliu, M.; Angulo, J.A. Epigallocatechin Gallate Mitigates the Methamphetamine-Induced Striatal Dopamine Terminal Toxicity by Preventing Oxidative Stress in the Mouse Brain. Neurotox. Res. 2020, 37, 883-892. [CrossRef] [PubMed] 
203. Chen, H.; Wu, J.; Zhang, J.; Fujita, Y.; Ishima, T.; Iyo, M.; Hashimoto, K. Protective Effects of the Antioxidant Sulforaphane on Behavioral Changes and Neurotoxicity in Mice after the Administration of Methamphetamine. Psychopharmacology 2012, 222, 37-45. [CrossRef]

204. Wąsik, A.; Antkiewicz-Michaluk, L. The Mechanism of Neuroprotective Action of Natural Compounds. Pharmacol. Rep. 2017, 69, 851-860. [CrossRef] [PubMed]

205. Kanthasamy, K.; Gordon, R.; Jin, H.; Anantharam, V.; Ali, S.; G. Kanthasamy, A.; Kanthasamy, A. Neuroprotective Effect of Resveratrol Against Methamphetamine-Induced Dopaminergic Apoptotic Cell Death in a Cell Culture Model of Neurotoxicity. Curr. Neuropharmacol. 2011, 9, 49-53. [CrossRef] [PubMed]

206. Devi, L.; Ohno, M. 7,8-Dihydroxyflavone, a Small-Molecule TrkB Agonist, Reverses Memory Deficits and BACE1 Elevation in a Mouse Model of Alzheimer's Disease. Neuropsychopharmacology 2012, 37, 434-444. [CrossRef] [PubMed]

207. Ren, Q.; Zhang, J.-C.; Ma, M.; Fujita, Y.; Wu, J.; Hashimoto, K. 7,8-Dihydroxyflavone, a TrkB Agonist, Attenuates Behavioral Abnormalities and Neurotoxicity in Mice after Administration of Methamphetamine. Psychopharmacology 2014, 231, 159-166. [CrossRef] [PubMed] 